\title{
STRATEgies FOR Risk MANAGEMENT AND CORPORATE SOCIAL RESPONSIBILITY FOR OIL AND GAS COMPANIES IN EMERGING MARKETS
}

\author{
STEPHANIE STIMPSON, JAY TODESCO, AND AMY MAGINLEY*
}

\begin{abstract}
Oil and gas companies are constantly in search of opportunities to expand their resource base and create value. Emerging markets can provide companies with opportunities for significant rewards, especially in regions where oil and gas resources may be underdeveloped and where new technologies have not yet been exploited. However, emerging markets also pose numerous challenges and risks, which can potentially lead to significant legal and reputational damage. This article explores key legal risk areas for oil and gas companies in emerging markets and best practices for managing those risks and operating in a socially responsible way, recognizing that risk management centers around controlled and reasoned decision-making, not eliminating risk. The article is intended to provide a high-level overview of the key legal risk areas and mitigation strategies to serve as a guide for directors and management teams operating in these challenging regions as opposed to providing a comprehensive discussion on any particular risk area.
\end{abstract}

\section{TABLE OF CONTENTS}

I. INTRODUCTION ................................ 260

II. The Duty to MANAGE AND Disclose Risks $\ldots \ldots \ldots \ldots \ldots \ldots . \ldots 261$

A. ROLES AND RESPONSIBILITIES OF OFFICERS AND DIRECTORS .... 261

B. OSC GUIDANCE FOR OFFICERS AND

DiRECTORS IN EMERGING MARKETS $\ldots \ldots \ldots \ldots \ldots \ldots \ldots 263$

C. Due Diligence Defense And Business Judgment Rule . . . . . 264

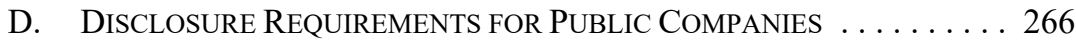

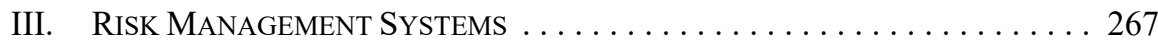

A. RisK MANAGEMENT SYSTEMS AND PROPORTIONALITY . . . . . . . 267

B. MONITORING . . . . . . . . . . . . . . . . . . . . . . . . . . . . 269

C. Litigation RiSK FROM THE RISK MANAGEMENT SYSTEM $\ldots . . . .269$

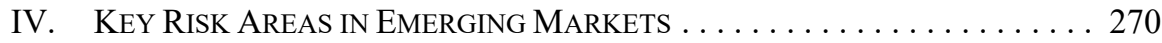

A. NATURE AND PRoteCtion OF THE INVESTMENT $\ldots \ldots \ldots \ldots \ldots .270$

B. Political Risk and Weak Rule of LAW . . . . . . . . . . 276

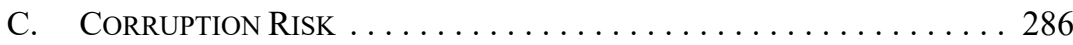

D. HumAn RightS AND COMMUNITY RELATIONS ............ 295

E. Security for the Project AND the USE of Security ForCes . . 302

F. EXTRATERRITORIAL LITIGATION AND

Piercing the Corporate VeIL . . . . . . . . . . . . . . . . . 305

G. Protecting Employees AbroAd . . . . . . . . . . . . . . . 308

Stephanie Stimpson is a partner at Torys LLP, Jay Todesco is Assistant General Counsel at Nexen Energy ULC, and Amy Maginley is an associate at Torys LLP. The authors would like to thank Gino Bruni, Brandon Rasula, and Kay Turner of Torys LLP for their research and assistance in the preparation of this article. This article focuses on strategies for risk management and corporate responsibility for oil and gas companies; however, many of the topics covered in this article relate to and are instructive for other types of energy and resource companies operating in emerging markets. 
H. Contracting ANd InSURAnCE Protocols . . . . . . . . . . 312

V. CONCLUSION ............................. 314

APPENDIX A: CANADA's CORPORATE

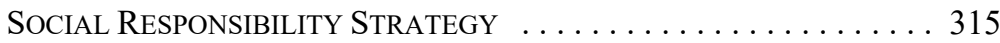

APPENDIX B: SUMMARY OF THE EXTRACTIVE SECTOR

TRANSPARENCY MEASURES ACT . . . . . . . . . . . . . . . . . . . . . . . 320

\section{INTRODUCTION}

Oil and gas companies struggle to find new growth opportunities in mature basins. Remote and undeveloped regions of the world offer the potential for significant value creation with their abundant and often under-exploited oil and gas resources. However, along with these opportunities and potential rewards, emerging markets present substantial obstacles and risks, as these regions can be plagued with numerous problems, including unstable political systems, weak rule of law, corruption, lack of transparency, and human rights issues. Companies are exposed to significant legal and reputational risks if they do not effectively identify and manage the challenges and risks in these regions. In recent years, directors and officers of companies operating in these regions have been subject to increased scrutiny. In the wake of the Sino-Forest scandal in 2011, ${ }^{1}$ the Ontario Securities Commission (OSC) commenced a regulatory review of selected "emerging market issuers." 2 The OSC's report concluded that there were often deficiencies in the level of oversight and stewardship of emerging market issuers, observing that "many risks were not appropriately identified, understood or managed by the board.",3

The mining and oil and gas industries have become a focal point of several of the Canadian government's latest initiatives to improve Canadian companies' reputations abroad as good corporate citizens, including through its recently enhanced Corporate Social Responsibility (CSR) strategy (Enhanced CSR Strategy) ${ }^{4}$ and the new Extractive Sector

Sino-Forest, which claimed to control approximately $\$ 3$ billion worth of timber assets through various entities in China, was accused in 2011 of fraudulently inflating its assets and earnings. In the Statement of Allegations filed by the Ontario Securities Commission (the OSC), the OSC alleged Sino-Forest had "falsified the evidence of ownership for the vast majority of its timber holdings by engaging in a deceitful documentation process." Re Sino-Forest Corporation (Statement of Allegations) (22 May 2012) at 4, online: OSC <www.osc.gov.on.ca/documents/en/Proceedings-SOA/soa_20120522_sinoforest.pdf $>$.

As noted by the OSC, the term "emerging market" has different meanings in different contexts, and the OSC's review focused on selected emerging market issuers whose mind and management was largely outside of Canada and whose principal active operations were in regions such as Asia, Africa, South America and Eastern Europe. OSC, Emerging Markets Issuer Review, OSC Notice 51-719 (20 March 2012) at 2-3, online: <https://www.osc.gov.on.ca/documents/en/Securities-Category5/sn 20120320 51-719_emerging-markets.pdf $>$. Harvard Business Review has defined emerging markets as markets that "offer the prospect of substantial growth because they have developed at least some of the institutions necessary to encourage commerce ... [b] ut institutional voids are still common enough to cause market failures; as a result, companies in emerging markets often have to perform these basic functions themselves": Tarun Khanna \& Krishna G Palepu, "Why Focused Strategies May Be Wrong for Emerging Markets," Harvard Business Review (July-August 1997) 41 at 42, online: <https://hbr.org/ 1997/07/why-focused-strategies-may-be-wrong-for-emerging-markets>. Issuer Guide for Companies Operating in Emerging Markets, OSC Notice 51-720 (9 November 2012) at 5, online: <https://www.osc.gov.on.ca/documents/en/Securities-Category5/sn_20121109_51-720 issuer-guide.pdf $>$ [OSC Emerging Market Guide].

Foreign Affairs, Trade and Development Canada, Doing Business the Canadian Way: A Strategy to Advance Corporate Social Responsibility in Canada's Extractive Sector Abroad (Ottawa: FATDC, 14 November 2014), online: <www.international.gc.ca/trade-agreements-accords-commerciaux/assets/pdfs/ Enhanced_CS_Strategy_ENG.pdf $>$ [Enhanced CSR Strategy]. An overview of the Enhanced CSR Strategy can be found in Appendix A, below. 
Transparency Measures Act. ${ }^{5}$ The Department of Foreign Affairs, Trade and Development Canada's (DFATD) Enhanced CSR Strategy is designed to encourage Canadian resource companies operating in emerging markets to adopt CSR best practices and now makes the Canadian government's "economic diplomacy" conditional on alignment with the Enhanced CSR Strategy. The ESTMA, which was proclaimed into force on 1 June 2015, is consistent with legislative efforts in other countries to improve transparent reporting of government payments to combat global corruption.

This article explores key legal risk areas ${ }^{6}$ for oil and gas companies in emerging markets and best practices for managing those risks and operating in a socially responsible way, recognizing that risk management centers around controlled and reasoned decision-making, not eliminating risk. This article is intended to provide a high-level overview of the key legal risk areas and mitigation strategies to serve as a guide for directors and management teams operating in these challenging regions as opposed to providing a comprehensive discussion on any particular risk area. This article is divided into five parts. Following this part, Part II outlines the duties of officers and directors with respect to identifying, managing, and disclosing risks. Part III describes how a risk management system should be developed, tailored, and maintained to identify and manage risks in emerging markets. Part IV identifies key risk areas in emerging markets and outlines various mitigation strategies that can be employed in order to manage those risks. Finally, Part V provides a brief summary and conclusion.

\section{The Duty to Manage AND Disclose Risks}

\section{A. Roles AND ResPonsibiLities OF OFFICERS AND DiReCtORS}

The role of the board of directors is to supervise the management of the business and affairs of the corporation. ${ }^{7}$ Directors are not required to be involved in day-to-day risk management, but rather have an oversight role to ensure that the corporation has appropriate risk management policies and procedures in place that are consistent with the business strategy and risk management philosophy endorsed by the directors. ${ }^{8}$ In discharging their responsibilities, directors and officers are held to the standards and must discharge those fiduciary duties prescribed under statute and at common law. The directors' and officers' duty of loyalty requires that they act "honestly and in good faith with a view to the best interests of the corporation." The Supreme Court of Canada has recognized that acting in the "best interests of the corporation" may require directors to consider the interests of all stakeholders, not only the interests of its shareholders, and such other stakeholders may include employees, suppliers, creditors, consumers, governments, and the environment. ${ }^{10} \mathrm{~A}$

5 Extractive Sector Transparency Measures Act, SC 2014, c 39, s 376 [ESTMA]. See Appendix B for a summary of the ESTMA.

This article does not address financial risks, such as commodity price risk, currency or exchange rate risk, cyber risks, nor technical, geological or other operational risks.

Business Corporations Act, RSA 2000, c B-9, s 101(1) [ABCA].

International Corporate Governance Network, ICGN Corporate Risk Oversight Guidelines (London: International Corporate Governance Network, 2010) at the preamble, online: $<$ https://www.icgn. org/file/589/download?token=LtefA5zi> [ICGN Guidelines].

9 This duty is prescribed in Canadian corporate law statutes: see e.g. ABCA, supra note 7, s 122(1)(a).

10 BCE Inc v 1976 Debentureholders, 2008 SCC 69, [2008] 3 SCR 560 at para 39 [BCE]; Peoples Department Stores Inc (Trustee of) v Wise, 2004 SCC 68, [2004] 3 SCR 461 at paras 64 -65 [Peoples]. 
director's and officer's "duty of care" requires the individual to "exercise the care, diligence and skill that a reasonably prudent person would exercise in comparable circumstances." 11 In practice, this requires that directors and officers must make informed judgments taking into account all material information reasonably available. They must take an active and direct role in material matters and must not be passive, and, when relying on information provided by management experts or others, there must be reasonable grounds for doing so. ${ }^{12}$

The Canadian Securities Administrators' Corporate Governance Guidelines state that the board of public companies should adopt a written mandate in which it explicitly acknowledges responsibility for, among other things, "the identification of the principal risks of the issuer's business, and ensuring the implementation of appropriate systems to manage these risks." ${ }^{13}$ The ICGN Guidelines provide that "[s]trategy, risk tolerance and risk are inseparable and should be connected in all discussions in the board."14 Management is responsible for the company's day-to-day risk management practices and will be accountable to the board to design and implement a risk management system that "correlates with the risk tolerance of the organisation" as determined by the board. ${ }^{15}$

The manner in which a company's risk management responsibilities are conducted and supervised will vary based on the size and nature of the company and where it conducts business. In a multinational corporation operating in emerging markets and other regions of the world, the corporate structure and identity of officers and directors may vary widely from one company to another. The board members of a public parent company are unlikely to have an officer or director role in a subsidiary in an emerging market and, instead, those board members will provide a risk oversight role on an enterprise-wide basis. On the other hand, members of the management team may have an officer or director role in a foreign subsidiary and play a more active role in directing the company's activities abroad. A board of a small company may be more directly involved in risk management activities than the board of a multinational corporation but, at the same time, may be more financially constrained in its due diligence and resources. In all cases, the officers and directors must be properly informed

ABCA, supra note $7, \mathrm{~s} 122(1)(\mathrm{b})$.

Torys LLP, Responsibilities of Directors in Canada - A Business Law Guide (Toronto: Torys LLP, 2009) at 17-18, online: $<$ www.torys.com/ /media/files/insights/trends-and-guides/responsibilities_of directors.pdf $>$.

Corporate Governance Guidelines, ASC NP 58-201 (30 June 2005), s 3.4(c). Within the board, aspects of the oversight role for risk management are often delegated to relevant committees of the board. The Committee of Sponsoring Organizations of the Treadway Commission's Enterprise Risk Management - Integrated Framework describes the roles and responsibilities within the organization for risk management and notes that the process must be "improved continuously as the business environment changes": Committee of Sponsoring Organizations of the Treadway Commission, Enterprise Risk Management - Integrated Framework (New York: American Institute of Public Accountants, 2004) at 48 [COSO ERM Framework]. See also Committee of Sponsoring Organizations of the Treadway Commission, Effective Enterprise Risk Oversight, The Role of the Board of Directors (New York: COSO, 2009), online: <www.coso.org/documents/COSOBoardsERM4pager-FINALRELEASE VERSION82409_001.pdf $>$.

ICGN Guidelines, supra note 8 at 1.1.1. See also the Conference Board Governance Centre's 2014 article Risk Oversight: Evolving Expectations for Boards, which discussed the evolving expectations for board oversight of management's risk appetite and tolerance and emphasized the importance of board training to ensure the board has the appropriate risk governance skills: Parveen P Gupta \& Tim J Leech, Risk Oversight: Evolving Expectations for Boards (New York: Conference Board Governance Center, January 2014) at 9, online: Financial Stability Board <www.financialstabilityboard.org/wpcontent/uploads/c 140206w.pdf $>$ [Risk Oversight]. The Conference Board provided at Exhibit 1 a sample Corporate $\bar{R}$ isk Management Policy that outlined risk management principles and risk assessment methodology, as well as delineated risk management responsibilities throughout the organization. ICGN Guidelines, ibid. 
and trained on the key risk areas impacting the company's business and assets in the emerging market and the systems and controls that should be in place to manage those risks.

\title{
B. OSC GUIDANCE FOR OFFICERS AND DIRECTORS IN EMERGING MARKETS
}

The purpose of the OSC Emerging Market Guide is "to provide assistance to emerging market issuers and their directors and management on their governance and disclosure practices in light of the unique challenges they face." 16 The OSC questioned, in part, the "extent of knowledge of boards ... of the cultural and business practices of the jurisdictions in which the issuer operated" and the board's understanding and management of risks. ${ }^{17}$ The OSC noted that boards of directors of emerging market issuers face a "steeper learning curve" to understand the business environment and risks, and that the effort and burden for directors to ensure they are properly informed and diligent in their decision-making is often higher for companies operating in emerging markets. ${ }^{18}$ The OSC provided a list of areas in which a board should enhance its knowledge and make inquiries, including the foreign government's role, the legal and regulatory environment, the company's right to operate, management of government relations, access to expertise, banking customs and arrangements, transferring funds, site visits, maintenance of books and records, and relationships with major suppliers and customers. ${ }^{19}$ The OSC cautioned:

\begin{abstract}
Boards of companies whose principal operations are located in an emerging market should be particularly sensitive to the risks associated with operations in those markets, especially those that may result in serious disruption to, or significant adverse impact on, business operations. Board members should ensure that they have a sufficient understanding of the legal, regulatory, political and cultural risks impacting the company and evaluate these risks in the context of the particular emerging market. ${ }^{20}$
\end{abstract}

The OSC highlighted the practical challenges associated with language barriers, physical distance, cultural differences, and communication, and emphasized the need for site visits,

OSC Emerging Market Guide, supra note 3 at 7. On 13 July 2015, the Toronto Stock Exchange (TSX) released a staff notice intended to provide guidance on the application of the TSX's original and continued listing requirements to emerging market issuers, which the TSX considers to have a higher risk profile. The TSX identified the following as principal areas relevant to listings in which there may be greater risks associated with emerging market issuers: (i) Management and Corporate Governance; (ii) Financial Reporting; (iii) Adequacy of Internal Controls; (iv) Non-Traditional Corporate/Capital Structures; and (v) Legal Matters Relating to Title and Ability to Conduct Operations: Parts III, IV and VII Emerging Market Issuers, TSX Notice 2015-0001 (13 July 2015), online: Toronto Stock Exchange $<$ tmx.complinet.com/en/display/display.html?rbid=2072\&element id=918> [TSX Staff Notice].

OSC Emerging Market Guide, ibid at 5, 7.

Ibid at 6 .

Ibid at $9-10$.

Ibid at 21. The OSC listed the following examples of prominent risks in emerging markets:

(1) political factors, including political instability and arbitrary or sudden changes to laws;

(2) the legal and regulatory framework in the foreign jurisdiction which may increase the likelihood that laws will not be enforced and judgments will not be upheld;

(3) the movement and conversion of currency out of the foreign jurisdiction, which could hinder the payment of dividends or other distributions to Canadian investors;

(4) corruption, bribery (including possible prosecution under the federal Corruption of Foreign Public Officials Act), civil unrest and economic uncertainty, which may negatively impact and disrupt business operations;

(5) factors that may affect the company's title to its assets;

(6) potential expropriation or nationalization of assets; and

(7) access to assets. 
director training, and board composition that included directors with strong international backgrounds and a deep understanding of the unique risks that can be presented. ${ }^{21}$

\section{Due Diligence Defense And Business Judgment Rule}

In assessing whether directors and officers have satisfied their duties, courts are typically very deferential to directors and their respective business decisions (in the absence of bad faith or conflicts of interest) and have been understandably reluctant to impose personal liability on directors provided an appropriate process for oversight and risk management was in place. $^{22}$ Many sources of director and officer liability are subject to a "due diligence defence" whereby the individual may avoid liability or punishment if he or she can demonstrate having exercised a degree of care, diligence, and skill that a reasonably prudent person would have exercised in comparable circumstances. ${ }^{23}$ The business judgment rule applies as a defence to claims that an officer or director breached his or her duty of care, based on the principle that, so long as the individual made decisions honestly and on a reasonable and informed basis regarding matters of business, courts should not substitute such decisions with their own opinions on such matters. ${ }^{24}$ The focus is whether the directors made a reasonable decision, not a perfect decision. ${ }^{25}$

While the courts have been reluctant to impose personal liability on directors in respect of their risk management role, the case law emphasizes the importance of having an appropriate process for oversight and risk management and that a good faith attempt is made to establish an internal reporting system designed to ensure the company and its employees comply with the law. The types of concerns identified by the OSC Emerging Market Guide were highlighted by the Delaware Court of Chancery in Re Puda Coal Stockholders Litigation. ${ }^{26}$ In Puda Coal, shareholders sued the directors of a company with operations in China after an investigation found that two Chinese directors had stolen the company's assets. In dismissing the independent directors' motion to dismiss the breach of fiduciary duty claims, the Court stated:

[I]f you're going to have a company domiciled for purposes of its relations with its investors in Delaware and the assets and operations of that company are situated in China ... in order for you to meet your obligation of good faith, you better have your physical body in China an awful lot.... You better have the

Ibid at $11-12$.

See Peoples, supra note 10; BCE, supra note 10. In both cases, the Supreme Court was reluctant to second-guess the business decisions of the directors and instead considered whether an appropriate degree of prudence and diligence was used in reaching the relevant decision. Prominent cases in the United States examining the directors' oversight role include: Re Caremark International Inc Derivative Litigation, 698 A (2d) 959 (Del Ch 1996) [Re Caremark]; Re Goldman Sachs Group, Inc Shareholder Litigation, 2011 WL 4826104 (Del Ch) [Re Goldman Sachs]; Re Citigroup Inc Shareholder Derivative Litigation, 964 A (2d) 106 (Del Ch 2009) [Re Citigroup Inc]; Stone v Ritter, 911 A (2d) 362 (Del Sup $\mathrm{Ct}$ 2006). Re Caremark confirmed a high threshold for finding directors personally liable, as the Court opined that liability would be found only where there is a "sustained or systematic failure of the board to exercise oversight" (Re Caremark, ibid at 971). The Court further noted that "a demanding test of liability in an oversight context is probably beneficial ... since it makes board service by qualified persons more likely, while continuing to act as a stimulus to good faith performance of duty by such directors" (ibid).

ABCA, supra 7, s 1221(1)(b); Peoples, supra note 10; BCE, supra note 10.

Peoples, ibid at para 65.

Ibid; BCE, supra note 10 at para 40.

(7 February 2013), Delaware 6476-CS (Del Ch) [Puda Coal]. See also Re Caremark, supra note 22. 
language skills to navigate the environment in which the company is operating. You better have retained accountants and lawyers who are fit to the task of maintaining a system of controls over a public company.... You have to have a system.

[I]f the assets are in [emerging markets] you're not going to be able to sit in your home in the U.S. and do a conference call four times a year and discharge your duty of loyalty.... [T] here will be special challenges that deal with linguistic, cultural and others in terms of the effort that you have to put in to discharge your duty of loyalty. ${ }^{27}$

To have the benefit of the due diligence or business judgment defences, the officers and directors must be properly informed and ensure that the company has proper procedures and policies in place for compliance. Officers and directors must not be complacent; they must properly investigate and address red flags and issues when they arise and cannot turn a blind eye to risks. ${ }^{28}$ Companies must carry out tailored due diligence exercises and seek out independent and trustworthy sources of information, which can be difficult in jurisdictions with nascent governments, legal regimes and a smaller educated class of experts. To inform themselves about a particular country and political environment, companies often seek information from legal and accounting firms, independent economic and political analysts, host government organizations, other oil and gas companies, and industry associations. Officers and directors should inquire about the sources of information and ensure the advisors providing the information are qualified and reputable, including evaluating the independence, qualifications, and level of diligence exercised by the local advisors. ${ }^{29}$

Puda Coal, ibid at 17-18, 21. These concerns are reflected in the TSX Staff Notice, supra note 16. The TSX, in providing guidance to emerging market issuers as to how they can mitigate concerns of the TSX with respect to new and continuous listings, stated that: (i) the TSX generally expects that independent directors will carry out regular site visits at the location of principal business operations with local management; (ii) that at least one director should have significant knowledge and experience regarding the jurisdiction where the issuer principally conducts its business; and (iii) where management and board members are not all fluent in a common language or present in similar time zones, the TSX may require that the issuer present a communication plan to satisfactorily demonstrate how effective communication will occur (ibid at Part II, ss 2(b), 2(c), 2(d).

28 In $R v$ Briscoe, 2010 SCC 13, [2010] 1 SCR 411, the leading Supreme Court of Canada case on this topic, the Court explained the doctrine of wilful blindness as follows:

[W]ilful blindness, correctly delineated, is distinct from recklessness and involves no departure

from the subjective inquiry into the accused's state of mind which must be undertaken to establish an aider or abettor's knowledge.

Wilful blindness does not define the mens rea required for particular offences. Rather, it can substitute for actual knowledge whenever knowledge is a component of the mens rea. The doctrine of wilful blindness imputes knowledge to an accused whose suspicion is aroused to the point where he or she sees the need for further inquiries, but deliberately chooses not to make those inquiries (ibid at paras 20-21 [emphasis in original]).

For consideration of "willful blindness" in the context of corporate liability for corrupt acts of agents, see Paul Blyschak, "Corporate Liability for Foreign Corrupt Practices under Canadian Law" (2014) 59:3 McGill LJ 655 at $673-84$.

29 The OSC noted that "[i]ndustry professionals in the emerging market may not be subject to equivalent rules of professional conduct and standards of care as they would be in the Canadian market": OSC Emerging Market Guide, supra note 3 at 29. 


\section{Disclosure ReQuirements For Public Companies}

Public companies must also comply with disclosure requirements related to the risks they face. The Alberta Securities Commission requires that reporting issuers disclose, "in order of seriousness," the risk factors relating to the company and its business. ${ }^{30}$ Boards and management should ensure that disclosures relating to risks of operating in emerging markets are specific to each corporate entity operating in such market. As noted in the OSC Emerging Market Guide, these disclosures are "an important element of investor protection" and a company's disclosure should "describe the process used by the board to oversee the risk management process" and "describe the company's risk management strategy and the systems that management has in place to manage and mitigate the risks of operating in emerging markets." 31

However, when unexpected events arise, it can often be difficult to determine when a matter is ripe for disclosure and the type of disclosure to include, particularly in volatile situations where information is difficult to obtain and facts are changing rapidly. The company should have reliable sources of information and experienced legal, political, and other advisors identified in advance and readily available to assist in order to ensure the company is acting in a timely manner based on the most reliable information possible. There will be additional disclosure challenges if the matter relates to something that the host government does not wish to have disclosed or that is covered under a confidentiality clause. These matters must be navigated carefully as the disclosure obligations under securities laws and stock exchange rules may be in conflict with local laws or the government contract (or even if not technically in conflict, may involve politically sensitive information that may be objectionable to the host government). Disclosure obligations and practices should be a component of emergency preparedness planning and management and the disclosure committee should discuss and conduct preparedness exercises on different scenarios and their approach to difficult disclosure situations.

See Annual Information Form, ASC NI 51-102F2 (30 June 2015), s 5.2 [Risk Factors]; ASC, Information Required in a Prospectus, NI 41-101F1 (30 June 2015) ss 1.10, 3.1(1)(d), 21. Securities regulators have also recognized that certain compensation structures and practices can encourage excessive risk-taking. Disclosure rules now require that companies disclose, among other things, whether the board of directors considered the implications of the risks associated with the company's compensation practices and any practices to identify and mitigate compensation practices that could encourage an executive "to take inappropriate or excessive risks": CSA Notice - Amendments to Form 51-102F6 Statement of Executive Compensation and Consequential Amendments, OSC CSA Notice, (2011) 34 OSCB 8047) at 8078.

31 OSC Emerging Market Guide, supra note 3 at 22, 24. See also the Investment Industry Regulatory Organization of Canada, Guidance Respecting Underwriting Due Diligence - Notice of issuance offinal guidance note and summary response to comments received (Toronto: IIROC, 18 December 2014), online: $<$ www.iiroc.ca/Documents/2014/d596ff2d-cd1a-48ea-8322-082b5f216e35_en.pdf $>$ (with respect to guidance on how due diligence should be undertaken to assess emerging market risks). See Michael Torrance, ed, IFC Performance Standards on Environmental \& Social Sustainability: A Guidebook, 1 st ed (Markham: LexisNexis Canada, 2012) at 320-23 [IFC Guidebook] (discussing the "inherent" materiality of disclosure regarding a company's human rights practices and violations). 


\section{RiSK MANAGEMENT SYSTEMS}

\section{A. Risk Management Systems And Proportionality}

To satisfy the risk management responsibilities discussed above, officers and directors must ensure that the company has a meaningful risk management strategy and that the concepts therein are properly described and communicated throughout the organization. "Risk" is generally defined as "the effect of uncertainties on corporate objectives" and the assessment and discussion of risk must be in the context of particular business objectives. ${ }^{32}$ As noted in the ICGN Guidelines, risk management is about controlled decision-making, not risk avoidance, and, in a healthy and dynamic market, profits are largely sourced from risk taking. ${ }^{33}$

There is no one-size-fits-all approach to risk management or assessing or mitigating risks. Each project, jurisdiction, and community will be subject to different risks, and the company's approach and response must be adapted to proportionally address the risks presented in the particular circumstances. Companies must consider the significance and priority of the risks presented and the costs and benefits of the mitigation measures that are implemented. ${ }^{34}$ Larger companies generally have comprehensive risk management systems in place with significant in-house expertise, and they are more easily able to absorb the costs of (1) comprehensive due diligence and thorough analyses of the legal requirements and risks presented in multiple jurisdictions; and (2) implementing sophisticated mitigation measures and protocols. In smaller companies, where there are less resources available, directors and officers must make informed judgments balancing the expenses and time that will be allocated to due diligence and the assessment and mitigation of various types of risks. As noted above, the board of directors must determine the risk tolerance and strategy of the company. ${ }^{35}$ The company's risk management systems must be tailored to that strategy and must be broadly applied across the organization and focus on identifying risks, estimating the probability and significance of the risks and the losses at stake, and the development of measures to mitigate such risks. ${ }^{36}$

ICGN Guidelines, supra note 8 at 4; Risk Oversight, supra note 14 at 8.

ICGN Guidelines, ibid.

IFC Guidebook, supra note 31 at 176; Risk Oversight, supra note 14 at 10.

The Conference Board Governance Center's report on the board's role in risk oversight recommended that:

[E]very board should be certain that:

1. the risk appetite implicit in the company's business model, strategy, and execution is appropriate

2. the expected risks are commensurate with the expected rewards

3. management has implemented a system to manage, monitor, and mitigate risk, and that system is appropriate given the company's business model and strategy

4. the risk management system informs the board of the major risks facing the company

5. an appropriate culture of risk-awareness exists throughout the organization

6. there is recognition that management of risk is essential to the successful execution of the company's strategy.

Tim Leech, Board Oversight of Management's Risk Appetite and Tolerance (New York: Conference Board Governance Centre, December 2012) at 2, online: <https://www.conference-board.org/retrieve file.cfm? filename $=$ TCB-DN-V4N23-12.pdf\&type $=$ subsite $>$.

$36 \quad$ Kristin N Johnson, “Addressing Gaps in the Dodd-Frank Act: Directors' Risk Management Oversight Obligations" (2011) 45:1 U Mich JL Ref 55 at 61-63. 
The Committee of Sponsoring Organizations of the Treadway Commission's (COSO) Enterprise Risk Management - Integrated Framework describes eight interrelated components of a risk management system as: Internal Environment (setting the tone for the company's risk management philosophy and risk appetite); Objective Setting (setting objectives that align with the company's strategy and its risk appetite); Event Identification (identifying internal and external events affecting achievement of objectives); Risk Assessment (analyzing and prioritizing risks, including likelihood and impact); Risk Response (developing actions that align with risk tolerance and appetite); Control Activities (ensuring the risk responses are carried out); Information and Communication (communicating effectively and in a timely manner); and Monitoring (ongoing review and modifications). ${ }^{37}$ The risk management system must recognize the effect of multiple risks that may compound under different circumstances and must aggregate such risks in order to have an "enterprise-wide view of risk." ${ }^{38}$ In other words, risks should not be viewed in isolation. For example, a human rights incident could give rise to immediate operational, government, community relations, security, litigation, and reputational risks, all of which may compound if the appropriate mitigation and response measures are not in place. As noted by COSO, risks do not exist in isolation and organizations therefore need to be aware that "[e]ven seemingly insignificant risks on their own have the potential, as they interact with other events and conditions, to cause great damage or create significant opportunity," which is why organizations should approach risk management with a holistic and integrated approach. ${ }^{39}$

There are a variety of risk management systems employed throughout the international petroleum industry. In certain cases where the company has an extensive portfolio of international operations or potential international opportunities, the risk management system should compare each of these operations or opportunities so as to provide a relative scale in assessing the risk areas as part of the decision making process on the investment. Where a company does not have an existing portfolio of international operations or a number of alternative international opportunities, the risk assessment can be done solely on the basis of the characteristics of the host country. This analysis usually starts with a study of available public information and then proceeds to in-country interviews with various stakeholders, including senior government officials, security experts, Canadian, US, and British commissions/ambassadors, business associations, community leaders, other energy and mining companies, service companies, multilateral organizations, and non-governmental organizations. The comprehensive study that arises out of this exercise should identify the various risks and mitigation strategies employed. It is important to note that risk analyses for opportunities may vary by reference to the particular areas within the specific country. For example, an offshore operation will have a different risk analysis than an operation to be conducted onshore; a project in an area of civil unrest will have a different profile than a

See COSO ERM Framework, supra note 13 at 3-4. The COSO ERM Framework supplemented the earlier COSO integrated internal control framework (focused primarily on financial controls), and covers a broader risk management focus. In October 2014, the Board of COSO announced a project to update the 2004 COSO ERM Framework, which is currently underway.

ICGN Guidelines, supra note 8, s 1.1.3.

Patchin Curtis \& Mark Carey, Risk Assessment in Practice (New York: COSO, October 2012) at 2, online: <www.coso.org/documents/COSOAnncsOnlineSurvy2GainInpt4Updt2IntrnlCntrlIntgratdFrm wrk\%20-\%20for\%20merge_files/COSO-ERM\%20Risk\%20Assessment $\% 20$ inPractice $\% 20$ Thought\%20Paper\%20OCtober\%202012.pdf> [COSO Risk Assessment]. In this publication, COSO provides tools for assessing and prioritizing risks within an organization. 
region of stability in that country; a populated area will have a different analysis than a remote area, and so on.

\section{B. MONITORING}

Regular monitoring of the risks and changes in the matters addressed in the company's risk matrix is critical to protect the company's operations, particularly in emerging markets due to the heightened volatility in those regions, including frequent changes to laws, fiscal regimes, business practices, government leaders, security, and civil disturbances. This requires "permanent and continuous risk assessment, preferably within a formal, enterprise-wide framework." ${ }^{40}$ Surprisingly, the Economist Intelligence Unit found that regular and continual monitoring of risk was the exception rather than the rule:

[T]he focus tends to be on testing the ground for planned investments, rather than on monitoring and managing risks to existing operations. This complacency is dangerous. Volatility is a defining feature of emerging markets and political risk will linger even as their contribution to global trade and economic activity grows. Companies that fail to recognise the continuous nature of risk in emerging markets may be exposing themselves to big losses in [the] future. ${ }^{41}$

In each region, there will be different areas of risk that will need to be monitored more carefully and updated more frequently; for example, while some risks may be effectively evaluated with a point-in-time analysis such as assessing the potential impact of recently announced legislation on operations, other risks, such as security risks, may be much more fluid and require constant monitoring to effectively assess potential risks to the operations. The approach should be tailored to the project and responsibilities for monitoring should be clearly delineated within the management team and organization. ${ }^{42}$

\section{Litigation RiSK FROM THE RiSK MANAGEMENT SYSTEM}

Similar to other areas of corporate governance and due diligence, the risk management system should expose risks and weaknesses in the company's current practices, as well as the assumptions and determinations that may have been made in reaching the business decisions to accept certain risks. In this regard, the risk management system itself may create or increase litigation risk. As noted by the Conference Board Governance Centre in Risk Oversight:

In litigious societies, particularly the United States, knowledge of a risk acceptance decision by senior management and sometimes the board, in the possession of a regulator, criminal prosecutor, or plaintiffs' bar armed with the benefit of hindsight, can significantly increase personal and corporate legal exposure for board members if the decision to accept such risk turns out badly for shareholders, key stakeholders, or society generally. 43

Economist Intelligence Unit, Operating Risk in Emerging Markets, (London, UK: Economist Intelligence Unit, 2006) at 7, online: <graphics.eiu.com/files/ad_pdfs/eiu_Operating_Risk_wp.pdf> [Operating Risk].

Ibid at 11 .

See COSO Risk Assessment, supra note 39.

Risk Oversight, supra note 14 at 7. 
Companies can try to protect against this litigation risk through the use of legal counsel to provide legal advice and direct the process of risk assessment under legal privilege when appropriate, but the limitations on this must be understood. In considering the applicability of solicitor-client privilege, it is important to note that solicitor-client privilege does not attach to every communication of a legal nature. ${ }^{44}$ In order for a communication to be covered by solicitor-client privilege, a communication must be between a lawyer and client, with the intention of being confidential, and made for the purpose of seeking or receiving legal advice. ${ }^{45}$ In this context, seeking legal advice on risks identified in the due diligence process could be beneficial, as privilege could be used to shield the legal analysis of such risks from the discovery process in the event of litigation. ${ }^{46}$ However, solicitor-client privilege will not necessarily extend to the conduct of the due diligence process itself. For example, when legal counsel is involved in conducting due diligence in the context of an acquisition or merger, diligence materials and documents will generally not be considered to be inherently privileged. ${ }^{47}$ This is because the purpose of such due diligence is to assist the corporation in ultimately making a business decision as to whether to proceed with a transaction, and therefore most of the diligence inquiries made are not legal inquiries gathered for the purpose of giving legal advice.

\section{KEY Risk AREAS IN EMERgING MARKETS}

For operations in emerging markets, the directors and management must ensure that the company's risk management system is tailored to the risks in that particular region. There are several key risk areas that are prominent in emerging markets including: (1) nature and Protection of the Investment; (2) political risk and weak rule of law; (3) corruption risk; (4) human rights and community relations; (5) security for the project and the use of security forces; (6) extraterritorial litigation and piercing the corporate veil; (7) protecting employees abroad; and (8) contracting and insurance protocols. A high-level description of each of those prominent risk areas is provided below, followed by strategies that can be implemented to manage and mitigate that particular risk area.

\section{A. Nature And Protection of the InVestment}

\section{RISK OVERVIEW}

Companies need to have a thorough understanding of the nature of their investment into a new region and the rights, obligations, and risks associated with that investment. Companies may acquire the subject interest through a direct or indirect acquisition of an existing interest or a direct government award, which may involve a formalized bidding process. The host government contracts or grants take various forms including concessions, exploration licenses, production leases, production sharing contracts, service arrangements, or a combination thereof (these are referred to generically herein as "host government

\footnotetext{
$44 \quad$ Solosky $v$ The Queen, [1980] 1 SCR 821 at 835.

$45 \quad$ Ibid at 837.

$46 \quad$ Yousuf Aftab, "The Intersection of Law and Corporate Social Responsibility: Human Rights Strategy and Litigation Readiness for Extractive-Sector Companies" (Paper delivered at the 60th Annual Rocky Mountain Mineral Law Institute Conference, Vail, Colorado, 18 July 2014) [unpublished] [Aftab, "Human Rights Strategy"].

47 L'Abbé v Allen-Vanguard, 2011 ONSC 7575, 2011 ONSC 7575 (CanLII) at paras 45-47.
} 
contracts"). Each form of host government contract will vary by jurisdiction, and some jurisdictions may have several different forms of host government contracts in place. If companies do not understand how to properly bid for or acquire their interest in an emerging market or how to comply with the requirements of the host government contract or local laws, they may not be able to obtain the asset or, following its acquisition, may be at risk of losing the asset. If the investment is not set up properly from a tax and corporate perspective, there can be significant tax and legal consequences. In the context of an acquisition, the acquirer will also be at risk of inheriting the liabilities of a predecessor company. There are also ever-increasing risks that a country, partner, or supplier may be subject to sanctions under various international laws.

\section{Mitigation StRATEgIES}

At the outset, there should be efforts made to identify and engage experienced legal counsel and other experts both in the host country and elsewhere to help the company navigate the legal requirements and government bureaucracy to avoid delays and misinformation. Business and industry guides should be reviewed to get an understanding of the basic political, legal, business, and operating regimes, which will assist in developing a thoughtful approach to entering a new country. Thorough, internationally focused due diligence checklists and procedures lists, tailored to the jurisdiction and type of interest or transaction, should be utilized. ${ }^{48}$

\section{a. Corporate Structure, Tax Planning, and Monetizing the Investment}

Both the corporate structure and tax analysis are critical planning items, and tax and legal advisors must be brought in at the earliest stage of entity formation and investment decision-making. The tax implications of available transaction structures (in the host country, in the investing company's home jurisdiction, and in any intermediary jurisdiction), including whether there are structures through which tax and other treaties may provide favourable treatment, must be evaluated by qualified advisors. The tax regime must be examined from various perspectives, including the country entry and exit standpoints, as well as what implications may arise while the entity is operating in the country. Tax rules and implications will vary from place to place for intercompany funding and service arrangements, transfer pricing rules (restricting intercompany charges), withholding tax and other taxes on distributions and loan repayments, import and export customs, value added tax, stamp tax, transfer tax, and other fees and duties. To understand the nature of the investment and maximization of value, the overall fiscal regime in the host country and throughout the corporate structure must be understood.

The company must also identify any foreign investment restrictions, both in the home jurisdiction and elsewhere, how the investment will be made and the types of government-regulated central banking or other approvals that are required, as well as any restrictions on currency exchange. ${ }^{49}$ With respect to repatriating funds, in addition to pure 
tax implications (for example, withholding tax and other taxes on distributions and loan repayments), there may be rigid government restrictions on the amounts and manner in which funds may be withdrawn from the country. The company must understand its ability to monetize its investment in the host country (either through returning cash flow from successful operations or through a partial or complete disposition), and whether government approvals or restrictions apply under those circumstances. There is a wide variation in the rules and how they are applied in different countries, and the tax and fiscal laws may be subject to change over time, particularly in emerging markets.

Careful adherence to Canadian mind and management principles is also critical to avoid inadvertent taxation of foreign income in Canada. The board and governance structure of the subsidiary, if one is incorporated for the purposes of the investment, must be reviewed and properly established prior to the investment and maintained throughout the term to ensure the company has an independent board with mind and management outside of Canada. A delegation of authority grid is required to ensure that appropriate internal controls govern corporate expenses and commitments. The mind and management considerations and their significance will vary for each jurisdiction depending on treaty treatment, local law requirements, and other considerations.

\section{b. Compliance with Local Laws and Contract Terms; Validity of Interest}

The legal regime and local laws should be reviewed with local counsel, including gaining an understanding of whether the country's legal regime is based on a common law regime, civil law regime, Sharia law, or some other form of laws. Legal practices and concepts vary widely from one place to another. At the early stages, the company will need to identify and understand the laws governing the petroleum regime in the host country, the host government contract, and the rights and commitments thereunder. The bid qualifications for the award of any host government contract must be carefully vetted, as there are often very specific bidding prerequisites and requirements for a license to operate, including requirements under the host government contract or applicable laws. For example, some countries require a corporate entity to hold the interest, while others allow a branch structure. There may also be requirements related to how long the entity has been in existence. There will generally be technical and financial qualifications for the company, and possibly parent guarantees, bonds, or other forms of financial support, which may have associated costs and implications under banking or other corporate documents. ${ }^{50}$ There can be lengthy time delays for preparing the necessary documentation and having it appropriately translated and legalized through specific channels. The company must confirm that all licensing, registration, entity establishment, or other local administrative requirements have been carefully satisfied (at the federal, state, and local level). 
The company must ensure the validity of the host government contract and any grant or transfer thereof. The host government contract must contain all the provisions that are required under the governing petroleum laws, and there may be a form of model contract or granting document that should be followed. ${ }^{51}$ Sometimes a host government contract is adopted or approved by law or is given the status of law. The regulatory process for the grant must be followed, including whether the grant must be subject to an open bid and public consultation, and with respect to government approvals that are required. There will be specific rules governing the various forms of host government contracts and their fiscal terms, some terms of which are negotiable and others are standardized. It is important to understand the strength of the contract or concession that the company has been granted, the commitments under that contract, and how it can be terminated or revoked by either party. To the extent the company requires stock exchange approval (for example, related to an acquisition, financing, or public offering), the applicable stock exchange will generally vet the legal interest and title to the assets and may require a title opinion from local counsel and certification from a "sponsor" (for example, the underwriter) that appropriate due diligence has been conducted. ${ }^{52}$

With respect to labour matters, there may be local content requirements for the use and training of local labour, and there may be nationalities that are banned from certain jurisdictions. The rules regarding immigration and work permits for foreign workers must be investigated, as well as tax implications. Certain jurisdictions have strong collective bargaining arrangements, work councils, or unions, which may impact operations and transactions in that region. The hiring practices, severance requirements, labour laws, and practices vary widely from place to place, and labour matters are commonly a very litigious area in emerging markets.

An accurate and reliable translation of the host government contract, other underlying agreements, and relevant laws must be obtained to ensure the requirements are understood and that the company remains in good standing. The official language of the host government contract must be clear to ensure that, in the case of ambiguity in interpreting a provision, or in the case of a dispute, the official version will prevail. In certain jurisdictions, it can be difficult to obtain current and up-to-date versions of statutes and regulations. ${ }^{53}$ It is common in emerging markets that practice may differ from the written law, as the legal or government systems may not be equipped to handle prescribed administrative or bureaucratic practices. This presents risks if a company follows customary practices that do not comply with

51 Caution should be exercised when state oil companies are involved to ensure their conduct and rights are consistent with the host government contract and with governing laws, including whether payments are to be made to the state oil company or the country's public treasury.

52 The TSX Staff Notice noted that "[f]or issuers operating in emerging market jurisdictions, if sponsorship is required, a site visit by the sponsor and commentary on the site visit by the sponsor will be required. Sponsors may also be asked to comment on local business practices which are not consistent with Canadian business practices. In addition, TSX may identify other areas of concern to be addressed by the sponsor such as ... local business knowledge, communication plan and related party transaction policy" (TSX Staff Notice, supra note 16, s 5).

53 Industry participants or trade associations may be a helpful resource for identifying and obtaining translations of applicable laws. In response to some of the difficulties navigating the legal landscape in many African nations, several African states have adopted a legal code under the Organization for the Harmonization of Business Law in Africa (OHADA), which currently has 17 member states: Organisation pour l'Harmonisation en Afrique du Droit des Affairs, Générale de l'OHADA, online: $<$ ohada.org/presentation-generale-de-lohada.html $>$. 
technical requirements under the law, as the government may choose to enforce the written law or use it as grounds to consider the company in breach or to renegotiate terms.

\section{c. Acquisitions and Successor Liability}

In the case of an acquisition of an interest in an existing host government contract from a third party, versus a direct government grant, there will be special considerations. The nature of government and third party approvals and preferential rights (rights of first offer or refusal) should be identified at the outset, including notification and approval requirements for asset and license transfers or changes of control. In addition to approvals required from the energy regulator, there may be government approval or notification requirements for foreign investments, competition and anti-monopoly reviews, tax authorities, central banking regulators, environmental permits, marketing or transportation matters, and other regulated matters which differ from country to country. There may also be strict confidentiality considerations by the host government, and a company may require approval of the host government prior to being provided access to a data room or being provided with confidential information.

The degree of due diligence will have to be expanded to include the past acts of the vendor in acquiring its interest and its conduct of subsequent operations, and will depend on the nature and duration of the interest, the reliability of the government registry system for petroleum rights, and whether the interest is jointly held. Due diligence will be required regarding any government claims of breach of the host government contract or governing laws, any third party claims to the host government contract or the area governed by the host government contract, or other potential title deficiencies or non-compliance. The company will also need to follow all transfer registration requirements to ensure a legally binding and enforceable interest is obtained that is recognized by the host state. For the acquisition agreement, customary representations, warranties, and indemnities should be included, as well as tailored provisions capturing the particular risks of that emerging market, such as whether the vendor is aware of any corruption, security or community relations issues that have arisen in connection with the project.

The company must assess risks based on whether the acquisition will be structured as an asset or share purchase. Where a company acquires an interest through a share acquisition, such as by way of a merger or other corporate consolidation, the successor corporation is liable for the debts and liabilities of its predecessor. ${ }^{54}$ In comparison, where a company acquires an interest pursuant to an asset purchase, even where the company may be acquiring all or substantially all of the vendor's assets, the company will generally not be liable for the debts and liabilities of the vendor unless such debts and liabilities were specifically assumed within the purchase and sale agreement. ${ }^{55}$ Obtaining an interest by way of an asset acquisition could therefore be a risk mitigation strategy for companies that are assessing

This is prescribed within Canadian corporate law statutes. See e.g. ABCA, supra note 7, s 186(c). For consideration of this issue in the context of corruption related to liabilities, see Blyschak, supra note 28 at 684-98. See also Central Sun Mining Inc v Vector Engineering Inc, 2011 ONSC 1439, 82 CCLT (3d) 164 at para 27 [Central Sun]. 
acquisitions as a means of entering emerging markets. ${ }^{56}$ However, companies should be aware that limited liability for asset acquisitions is not an absolute rule, and Canadian courts have recognized that the doctrine of "successor liability" could be applicable in certain cases. ${ }^{57}$ The successor liability doctrine recognizes that a purchaser in an asset purchase transaction could be found vicariously liable for the debts and liabilities of the vendor if one or more of the following apply: (1) the purchaser expressly or impliedly agreed to assume the debts or liabilities of the vendor; (2) the transaction resulted in a de facto merger; (3) the purchaser is a mere continuation of the vendor; or (4) the transaction is an effort by the parties to fraudulently avoid liability. ${ }^{58}$ In assessing whether a de facto merger or mere continuation has occurred, courts may assess a number of criteria including: (1) continuity of ownership between vendor and buyer corporations; (2) whether there was a cessation of ordinary business and dissolution of the predecessor as soon as practically and legally possible after the acquisition; (3) whether the purchaser assumed liabilities ordinarily necessary for the uninterrupted continuation of the business of the vendor; and (4) whether there was a continuity of management, personnel, physical location, assets, and general business operations after the acquisition. ${ }^{59}$

\section{d. Sanctions}

The company must also assess whether there are any sanctions that apply with respect to the host country or to any of the partners or entities involved in the project. Sanctions are restrictive measures imposed by governments against other countries, individuals, or entities that are used as a foreign policy tool to pursue certain objectives and bring about changes in policies or activities of the sanctioned party. Under the United Nations Act, ${ }^{60}$ Canada imposes sanctions adopted by resolutions of the United Nations Security Council, while other sanctions are imposed by Canada autonomously under Canada's Special Economic Measures Act. ${ }^{61}$ As noted on DFATD's website, sanctions can impact a business by (1) prohibiting trade or economic activities with a foreign market; (2) restricting financial transactions such as investments or acquisitions; or (3) leading to the seizure of property in Canada. ${ }^{62}$ The Acts outline criminal offences and penalties for each offence. ${ }^{63}$

Blyschak, ibid at 693. The issue of successor liability has been highlighted in a number of high-profile cases. For example, in Yaiguaje v Chevron Corporation, 2013 ONCA 758, 118 OR (3d) 1 [Chevron], Ecuadorian claimants who are seeking to enforce an Ecuadorian judgment for environmental liabilities in Canada have targeted Chevron for the payment of such liabilities based on the fact that Chevron purchased Texaco Inc in 2001 and therefore assumed Texaco's environmental liabilities in Ecuador. Central Sun, supra note 55.

58

RSC 1985, c U-2.

SC 1992, c 17 [SEM Act]. of sanction.

Blyschak, ibid; Ramirez v Amsted Industries Inc, 408 A (2d) 818 (NJ Sup Ct 1979).

Blyschak, ibid at 695; Central Sun, supra note 55 at para 40.

Foreign Affairs, Trade and Development Canada, "Current Sanctions Imposed by Canada," online: $<$ www.international.gc.ca/sanctions/countries-pays/index.aspx?lang=eng $>$. The DFATD website lists the types of sanctions that may be imposed and the current list of sanctions in place by the Canadian government. As of 1 June 2015, there were 22 countries against which Canada has imposed some form

See SEM Act, supra note 61, s 8. 
The application of sanctions and their impact on a project can be a very challenging consideration in respect of the changing nature of the companies, individuals, and countries subject to sanctions by various governments. Sanctions can also be applied where there is only minimal connection between the investment or project and the state seeking to impose the sanction. In addition to understanding sanctions that apply to countries where a company or its subsidiaries do business, companies must engage specialist advisors and expert advice to investigate whether potential partners, investors, service providers, and others (including entities who own or control those entities) are included on relevant sanction lists - whether for purposes of doing business in or sourcing materials from such countries. Even with thorough due diligence in advance of an investment, sanctions can change abruptly, with immediate effect, leaving companies to decipher the implications and the scope of permitted versus prohibited activities and relationships. ${ }^{64}$

\section{e. Cultural Differences}

Companies should carefully investigate cultural, religious, and ethnic practices and differences in the emerging markets in which they operate. These can vary widely from country to country and within regions and tribes within countries. Companies will need to educate themselves on these matters through local resources and will need to train expatriates travelling into those jurisdictions to ensure they are properly informed and versed in cultural protocols, including communication style, language and translation barriers, body language, the manner in which people show respect and address counterparts, gender issues, ideologies, religious practices and holidays, protocols for entertaining and social events, gift giving, and other cultural norms. These matters should be given significance at the outset of the project, as cultural understanding and respect will be critical for building good relationships with communities, governments, partners, service providers, labour forces, unions, and other groups. This will be a competitive advantage for the companies that do it well, and can have lasting reputational effects.

\section{B. Political Risk ANd Weak Rule of LAW}

\section{RISK OVERVIEW}

Energy projects in emerging markets, many of which have a long life-span and require significant capital expenditures prior to becoming economically viable, are subject to significant political risk regarding the sanctity of their contract and changes to the legal or fiscal regime governing the project. In these jurisdictions, there is often weak rule of law and the legal systems may be corrupt, bureaucratic, unpredictable, and subject to frequent changes in policy and leadership. As articulated in The Economist:

[A]n emerging market is one where politics matters at least as much as economics. This is because political institutions in emerging markets tend to be weak, and power is often captured by an unrepresentative elite. other resources, and the extent of its investments around the world: see Janet Guttsman, "Doing Business with the Bear," Canadian Lawyer Magazine (23 March 2015), online: <www.canadianlawyermag.com/ 5517/Doing-business-with-the-bear.html>. 
In such conditions, the process by which laws and regulations are drafted and applied is easily subverted, which means that investors can face a changeable and unpredictable operating environment. ${ }^{65}$

Control Risks defines political risk as "the likelihood of state or non-state political actors negatively affecting business operations in a country through regime instability or direct/indirect interference." ${ }^{\prime 66}$ Types of political risks may include: (1) breach of contract by the foreign government; (2) expropriation or nationalization; (3) adverse changes in laws, regulations, or contract terms; (4) foreign exchange or central banking restrictions; (5) import and export restrictions; and (6) civil disturbances and political turmoil. ${ }^{67}$ " [I]nvestors must develop proactive political-management strategies that lessen government officials' incentives to divert investors' returns.... [P]olitical mastery can become a source of competitive advantage in addition to a means of avoiding losses." ${ }^{.68}$ Frequent changes in government leaders and power struggles between government departments can create significant uncertainty on the ability to form and maintain good government relations in unstable countries. As government leadership changes, the new leaders may not be willing to abide by the policies and agreements of predecessor regimes; therefore, a strong relationship under one leader may become a hindrance upon a change in power. ${ }^{69}$

\section{Mitigation StRATEgies}

Political risk is one of the most challenging aspects of risk to manage, as the company may have little control over the political process or government stability in the emerging market, particularly for projects that have a long life span. At the outset, the company should evaluate the political risk rating of the host country as determined by independent international rating agencies and determine whether the host country is subject to any international sanctions. Political risk can be difficult to measure, but there are resources available to assess the political landscape and political decision-making. ${ }^{70}$ The company should investigate the applicable investment treaties and economic organizations (for example, the World Trade Organization) to which the host country is a party, the type of dispute resolution mechanisms available, the ability to enforce arbitration awards and the application of sovereign immunity in the host country.

Companies may attempt to protect themselves against political risks in a variety of ways, including: by structuring their investment through jurisdictions subject to international investment agreements; through the use of stabilization clauses and other contractual protections with the host government; by strict compliance with their contracts and local laws; by good corporate citizenship; by securing alternate dispute resolution with neutral

Control Risks Group, RiskMap Report 2014 (London: Control Risks Group, 2014) at 105, online: $<$ https://www.controlrisks.com/webcasts/studio/flipping-book/riskmap-report-2014/files/assets/ common/downloads/RiskMap\%202014\%20REPORT.pdf> [RiskMap].

67 Manuel A Abdala, "Key Damage Compensation Issues in Oil and Gas International Arbitration Cases" (2009) 24:3 Am U Intl L Rev 539.

Witold J Henisz \& Bennet A Zelner, "The Hidden Risks in Emerging Markets," Harvard Business Review (April 2010) 88 at 90, online: $<$ https://hbr.org/2010/04/the-hidden-risks-in-emerging-markets>. Ibid. For example, following the 1997 Asian financial crisis, Indonesia's military dictator, General Suharto, retained contracts for companies affiliated with his family and friends, while renegotiating contracts with foreign investors. After he was ousted, the successor government renegotiated the contracts of the previously favored entities (ibid at 92-93). Ibid. 
arbitration tribunals; through insurance (although the limitations of insurance must be recognized); by utilizing the influence of the home government; and by acting collectively through trade associations. Political risk may also be mitigated when recognized major oil and gas companies and financial institutions are involved in a project, such as the World Bank.

\section{a. Bilateral Investment Treaties and Investor Protection Agreements}

\section{i. Overview of Investor Protection Treaties and Agreements}

Emerging markets generally want to attract foreign investment, which can only be achieved with some level of economic stability. At the initial stages of the company's project and investment decision, consideration should be given to structuring the investment through vehicles subject to protections under a bilateral investment treaty (BIT) between countries or another form of investor protection agreement. ${ }^{71}$ A BIT is an agreement establishing the terms and conditions for private investment by nationals and companies of one state in another state to protect such investment against the risk of government interference. Canada refers to its agreements as "Foreign Investment Promotion and Protection Agreements" (FIPA) and as of 1 June 2015, has 29 FIPAs in place, with another seven underway. ${ }^{72}$ Companies can also refer to the United Nations Conference on Trade and Development (UNCTAD), which is governed by its 194 member states and is responsible for dealing with development and international trade issues. UNCTAD maintains a list of all outstanding BITs and international investment agreements. ${ }^{73}$

BITs contain certain obligations, or standards, required from host countries to protect investments from government interference. These standards address issues such as: the fair and equitable treatment of investors; protection of the investment from expropriation; protection that investors will not be treated less favourably than local companies or other third party states; full protection and security of the investment; and protections against arbitrariness and discrimination. ${ }^{74}$ While these standards are common across BITs, arbitration tribunals apply these standards differently, which can lead to uncertainty for investors due to the inconsistent application of such standards. ${ }^{75}$

A distinctive feature of many BITs is that they allow for an alternative dispute resolution mechanism, whereby an investor whose rights under the BIT have been violated will have recourse to an international arbitration tribunal, rather than suing the host government in its own courts, which is often the company's only recourse under a host government contract.

71 For further reading on this topic, see Elizabeth Whitsitt \& Nigel Bankes, "The Evolution of International Investment Law and Its Application to the Energy Sector" (2013) 51:2 Alta L Rev 207, which provides a thorough analysis of the legal framework for these arrangements in the energy sector, the types of investment law disputes that arise in the energy sector, and the remedies available under them. Foreign Affairs, Trade and Development Canada, "Canada's Foreign Investment Promotion and Protection Agreements (FIPAs)," online: <www.international.gc.ca/trade-agreements-accords-commer ciaux/agr-acc/fipa-apie/fipa-apie.aspx?lang=eng $>$.

73 United Nations Conference on Trade and Development, “About UNCTAD," online: <unctad.org/en/ Pages/AboutUs.aspx $>$.

74 Whitsitt \& Bankes, supra note 71 at 214

Ibid at $214,217,222-23$. 
A further discussion regarding the advantages of using arbitration in the context of enforcing BITs can be found in Part IV.B.2.d.ii (Dispute Resolution — Arbitration).

\section{ii. Remedies and Ability to Enforce Investor Protections}

When a breach of an investment protection agreement or BIT by the host government occurs, the available remedies must be assessed. The applicable governing contract, investment agreement, or BIT may express the remedies that are available; otherwise, arbitrators will apply the remedies available under international law generally. Restitution and compensation are the "dominant forms of reparation available to investors." been differing results in the enforcement of rights under BITs, highlighting the conflict between protecting investors' rights and the government's duty to regulate and protect the public interest.

A company's poor performance on environmental, human rights or other social responsibility fronts may serve as a basis under which a government may refuse to honour mandates under an applicable investment treaty. The International Center for the Settlement of Investment Disputes (ICSID), which is an arm of the World Bank, has dismissed claims from investors alleging a breach of a BIT by a host government where it was found that the investor was misusing the system of international investment protection in an effort to protect investments which were made contrary to public policy. ${ }^{77}$ For example, the ICSID denied investor protection to World Duty Free Company Limited, which was awarded a contract by Kenya to develop duty-free complexes in Kenyan airports, after it was found that the company had engaged in bribery to receive the contract. ${ }^{78}$ The ICSID has also refused to provide protection to companies where such companies engaged in fraudulent actions in order to win contracts through public bidding processes. ${ }^{79}$ On the other hand, in 2012, the ICSID awarded \$2.3 billion to Occidental Petroleum Corp., ruling that Ecuador had breached the United States-Ecuador BIT when it cancelled the company's contract and seized its assets in the country. ${ }^{80}$ The outcome of such disputes generally depends on principles of reasonableness, proportionality, and fairness. The facts must be carefully assessed as well as the jurisprudence related to the issues and provisions at stake. In some cases, a company may decide that rather than fight government actions, it is appropriate to renegotiate on certain points to avoid a protracted dispute.

Ibid at 237

Yousuf Aftab \& Rita Villanueva, "Human rights risks and the legal consequences of the guiding principles on business and human rights" (Paper delivered at the 2 nd International Conference on Social Responsibility in Mining, Santiago, Chile, 5 November 2013), online: Enodo Rights <static1.square space.com/static/50c2b14ae4b0ceeebffc64d3/t/52e2ea3ce4b004adfb557fa7/1390602812762/SR+Mi ning+Publication+\%28Beyond+Social+License\%29.pdf $>$ [Aftab \& Villanueva, "Guiding Principles"]. Further, as noted in Aftab, "Human Rights Strategy," supra note 46: "[w]hen it comes to respect for human rights, general principles of law and transnational public policy become relevant at the threshold level of determining whether an investor is entitled to BIT protection in the face of government interference" (ibid at 16).

78 World Duty Free Co v Kenya, ICSID Case No ARB/00/7 (4 October 2006) at para 157, online: italaw $<$ www.italaw.com/documents/WDFv.KenyaAward.pdf>.

Inceysa Vallisoletana, SL v El Salvador, ICSID Case No ARB/03/26 (2 August 2006), online: italaw $<$ www.italaw.com/sites/default/files/case-documents/ita0424_0.pdf $>$.

Occidental Petroleum Corp v Ecuador, ICSID Case No ARB/06/11 (5 October 2012), online: italaw $<$ www.italaw.com/sites/default/files/case-documents/italaw1094.pdf $>$; Lexpert, "Energy sector driving major growth in international arbitration," Lexpert (1 February 2014), online: <www.lexpert.ca/ magazine/article/energy-sector-driving-major-growth-in-international-arbitration-2626/> [Lexpert, "Energy"]. 


\title{
b. Stabilization Clauses and other Contractual Guarantees
}

\section{i. Overview and Types of Stabilization Clauses}

Stabilization clauses are "contractual clauses in private contracts between investors and host states that address the issue of changes in law in the host state during the life of the project." 81 The aim of stabilization clauses is to insulate the project from adverse changes to the legal and fiscal environment. The main types of stabilization clauses are "freezing clauses," “equilibrium clauses," and "hybrid clauses," although equilibrium clauses are much more common today. ${ }^{82}$ Freezing clauses exempt an investment from the application of new legal requirements, either in its entirety or limited to certain areas such as fiscal matters, while equilibrium clauses compensate the financial loss resulting from changes in law and stabilize the economic return for the investor. ${ }^{83}$ Hybrid clauses provide the parties to the contract with an option as to whether the investor will be protected either through an exemption from regulatory change or through other forms of alleviation measures. ${ }^{84}$

\section{An example of a stabilization clause is as follows:}

\begin{abstract}
The rights and interests accruing to Company (or its assignees) under this Agreement and its subcontractors used in the conduct of operations hereunder shall not be amended, modified or reduced without the prior consent of the Company. In the event that any Governmental Authority invokes any present or future law, treaty, intergovernmental agreement, decree or administrative order which contravenes the provisions of this Agreement or adversely or positively affects the rights or interests of the Company hereunder (or its subcontractors used in operations hereunder), including, but not limited to, any changes in tax legislation, regulations or administrative practice, or jurisdictional changes pertaining to the Contract Area, the terms of this Agreement shall be adjusted to re-establish the economic equilibrium of the Parties, and if the rights or interests of the Company (or its subcontractors used in operations hereunder) have been adversely affected, the [state oil company/Ministry/Government] shall indemnify the Company (and its assignees) for any disbenefit, deterioration in economic circumstances, loss or damages that ensue therefrom. The [state oil company/Ministry/Government] shall, within the full limits of its authority, use its reasonable lawful endeavors to ensure that the appropriate Governmental Authorities will take appropriate measures to resolve promptly in accordance with the foregoing principles any conflict or anomaly between any such treaty, intergovernmental agreement, law, decree or administrative order and this Agreement. ${ }^{85}$
\end{abstract}

An important function of the stabilization clauses is to include the rights of subcontractors so as to capture the entire value and operations chain.

Andrea Shemberg, "Stabilization Clauses and Human Rights," IFC/SRSG Research Paper (27 May 2009) at 4, online: International Finance Corporation<www.ifc.org/wps/wcm/connect/9feb5b00488555 eab8c4fa6a6515bb18/Stabilization\%2BPaper.pdf?MOD=AJPERES>. Evaristus Oshionebo, "Stabilization Contracts in Natural Resource Extraction Contracts: Legal, Economic and Social Implications for Developing Countries" (2010) 10 Asper Rev Intl Business \& Trade L 1 at 2 .

Katja Gehne \& Romulo Brillo, "Stabilization Clauses in International Investment Law: Beyond Balancing and Fair and Equitable Treatment" (2014) National Centre of Competence in Research Working Paper No 2013/46 at A(i), online: World Trade Institute <www.wti.org/fileadmin/ user_upload/nccr-trade.ch/wp2/Stab_clauses_final_final.pdf $>$.

Ibid.

Based on contract precedents from Torys LLP. 
In addition to seeking to obtain stabilization clauses, companies may attempt to protect the stability of their investments through other terms of the host government contract. For example, companies may negotiate favourable choice of law and forum selection provisions or obtain government guarantees on a number of investment matters. ${ }^{86}$ Depending on the negotiating power of the company, it may also be possible to obtain host government guarantees to address a number of risks, including guarantees regarding: (1) the rights to be granted by the host government under the host government contract; (2) the obligations undertaken or to be undertaken by the state oil company; and (3) that the government has, and shall maintain, throughout the entire term of the host government contract, the sole and exclusive jurisdiction over the contract area, and that the state oil company has full authority to grant the rights and interests to the company as provided in the host government contract. ${ }^{87}$

\section{ii. Remedies and Ability to Enforce Stabilization Clauses}

The remedies available to an investor when there is an alleged breach of a stabilization clause by the host government will be informed by the type of stabilization clause in the contracts, as well as the nature of the breach. ${ }^{88} \mathrm{~A}$ breach of a freezing stabilization clause will provide the investor with a cause of action for damages. ${ }^{89}$ In comparison, economic equilibrium clauses which, unlike freezing clauses, do not prevent the host state from amending or creating new regulations, require that the "economic equilibrium" of the contract be restored, which in some circumstances may provide the investor with a larger claim for compensation than would otherwise be received for a breach of a freezing clause..$^{90}$ Where arbitral tribunals find investors to be entitled to compensation, the amount of compensation to be paid to such investors can be influenced by a variety of factors, including: costs incurred by the investor due to the breach; the investor's legitimate expectations with respect to the presence of a stabilization clause (for example, whether the expectation under the investment agreement was that the investor would receive a reasonable rate of return on their investment); or loss suffered by the investor. ${ }^{91}$

86 For example, a choice of law provision might read:

This agreement shall be governed and interpreted in accordance with principles of law common to the law of the Host Government and English law, and to the extent that no common principles exist in relation to any matter then in accordance with the principles of the common law of Alberta, Canada [or another acceptable jurisdiction], except for laws regarding conflicts of laws. This Agreement shall also be subject to the international legal principle of pacta sunt servanda [agreements must be observed].

87 Other guarantees companies may negotiate could include: (1) that the government will not, during the term of the host government contract, enter into any treaties or other arrangements which would, directly or indirectly, diminish, infringe upon, nullify or derogate from the rights and interests of the company, and in the event any treaties or arrangements are entered into which concern the contract area or the company's rights in the host government contract, such treaties or arrangements will provide for express recognition and preservation of the company's rights; (2) that the company's rights, interests and property will not be expropriated or nationalized or otherwise be taken by any act or authority of the host government; (3) that no grant of rights to explore for or develop reserves in the contract area will be given to any other parties during the term of the host government contract (or any extension thereof); and (4) to the extent legislation does not already exist in the host country, the government shall take all measures to enact such legislation as necessary to enable foreign flag vessels to be registered under the host government flag, so that such vessels qualify to operate in the applicable international waters without violating any treaties.

Oshionebo, supra note 82 at 7.

Ibid at 16 .

Gehne \& Brillo, supra note 83 at A(ii).

Oshionebo, supra note 82 at 16; Lorenzo Cotula, "Reconciling Regulatory and Evolution of Environmental Standards in Investment Contracts: Towards a Rethink of Stabilization Clauses" (2008) 1:2 J World Energy L \& Business 158 at 166. 
Given the possible uncertainty in the calculation of any damage award, some host government contracts have been amended by the investing company to provide:

\begin{abstract}
If any of the Company's rights, interests or property are expropriated, nationalised or otherwise taken by reason of any act or failure to act of any Governmental Authority, then the arbitrators shall apply the principle of indemnification (including prompt, full and effective compensation in US Dollars) at the full market value, on the basis of an on-going concern utilising the discounted cash flow method, assuming a willing buyer and seller in a non-hostile environment, and disregarding the unfavourable circumstances under which or following which the Company shall be deprived of its rights, interest (including its interest in undeveloped reserves) or property. The arbitrators shall select an investment bank of good international reputation for purpose of appraising the full market value of said rights, interest (including its interest in undeveloped reserves) or property of the Company. ${ }^{92}$
\end{abstract}

Similar to BITs, the enforcement of these clauses over time has been challenged under both the domestic law of the host state and international law. ${ }^{93}$ Legal advice should be sought with respect to the legal enforceability of such clauses under local law, as well as whether there is precedent considering the issue at stake under international law. Certain stabilization clauses may be deemed to be unenforceable domestically, as the executive powers of the state may not be restricted by a contract with a private individual or corporation. ${ }^{94}$ The enforceability of a stabilization clause will also depend on whether it is consistent with the principles of international law. Some critics of stabilization clauses have argued that such clauses should be invalid under international law based on the principle that the host state has permanent sovereignty over their natural resources. ${ }^{95}$ Conversely, arbitral tribunals have also upheld stabilization clauses on the basis that a state's agreement to be bound by a stabilization clause is considered a valid exercise of that state's sovereignty. ${ }^{96}$

\title{
c. Strict Compliance with the Contract and Legal Requirements
}

As discussed above, rigorous compliance with the host government contract and applicable domestic laws will reduce the potential grounds under which the host government may assert claims for non-compliance or use non-compliance as a basis to impose additional requirements or otherwise renegotiate the terms of the contract. Again, an accurate and reliable translation of the contract or other underlying agreement and relevant laws must be obtained to ensure the requirements are understood and that the company remains in strict compliance with the contract. Companies should be readily prepared to defend their record of compliance through documented records. There should be standardized and detailed protocols regarding record keeping and document retention, including secure copies of key documents stored in the company's home jurisdiction. The company should retain copies of all government correspondence, as well as have procedures for note-taking and follow-up written correspondence where important discussions or commitments with government

Based on contract precedents from Torys LLP.

Oshionebo, supra note 82 at 4-5. Arguments have been made, for example, that freezing stabilization clauses are "unenforceable because they fetter the sovereign power of host States to make laws" (ibid at 8). Alternatively, the enforceability of stabilization clauses under domestic law have been questioned because "the Constitutions of some developing countries vest in the national legislature the power to make laws" (ibid at 11).

Ibid at 8 .

Ibid.

Ibid at 13; Gehne \& Brillo, supra note 83 at B(i). 
representatives are made verbally (as it may be difficult to secure written documentation from government officials). Strong record keeping and document retention practices can evidence compliance or act as proof of waivers or leniency by government officials.

\section{d. Dispute Resolution - Arbitration}

\section{i. $\quad$ Arbitration as Preferred Dispute Resolution in Emerging Markets}

In countries with weak rule of law and unreliable judicial systems, it is important to secure dispute resolution in a neutral forum to avoid the "home court advantage" of the host government as a litigant and and local courts that may be corrupt or biased. With respect to the type of dispute resolution that is selected, arbitration clauses are more widely utilized than courts for dispute resolution in host government contracts and emerging markets in particular due to the 1958 New York Convention on the Recognition and Enforcement of Foreign Arbitral Awards, ${ }^{97}$ which is a treaty under which 155 countries have agreed to enforce the arbitral awards made in other contracting states, and the ICSID, which has 159 member countries and is where most investor-state disputes are arbitrated. ${ }^{98}$ Arbitration rules allow the parties to choose certain aspects of dispute resolution procedures, can be simplified and flexible in comparison to court rules of civil procedure, and decisions are generally binding and can only be appealed in rare cases. Arbitration is also well-suited to disputes involving technical expertise, as the arbitrators can be selected based on their familiarity with the subject matter of the dispute. Arbitration is generally done on a confidential basis, which affords the parties more privacy than a public court action. However, there are certain limitations to arbitration. For example, it is difficult to join parties to the arbitration, unless all parties consent. In addition, the types of remedies available can be limited, although numerous jurisdictions, both inside and outside of Canada, have permitted arbitrators to grant equitable relief, which may depend on the wording of the arbitration clause as well as the applicable arbitration rules. ${ }^{99}$ For instance, in Alberta, section 31 of the Arbitration Act ${ }^{100}$ expressly permits an arbitrator to grant equitable relief. However, under the US Federal Arbitration $A c t^{101}$ and the New York Convention, ${ }^{102}$ the US federal courts do not have authority to confirm or enforce interlocutory awards; an award must be "final" in order for it to be subject to any court review. ${ }^{103}$

10 June 1958, 330 UNTS 38 (entered into force 7 June 1959) [New York Convention]. See also United Nations Commission on International Trade Law, Status of Convention on the Recognition and Enforcement of Foreign Arbitral Awards, online: <www.uncitral.org/uncitral/en/uncitral_texts/ arbitration/ NYConvention.html>.

Canada ratified the ICSID in 2013. International Centre for Settlement of Investment Disputes, Database of ICSID Member States, online: <https://icsid.worldbank.org/apps/ICSIDWEB/about/Pages/Databaseof-Member-States.aspx>. Lexpert, "Energy," supra note 80.

David Wotherspoon, "The Arbitration Tribunal and Equitable Relief: An Update from the British Columbia Court of Appeal," The Advocate (May 2009), online: Fasken Martineau LLP $<$ www.fasken. com/en/equitable-relief-update-british-columbia/>.

RSA 2000, c A-43, s 31.

US Federal Arbitration Act, c 213, 43 Stat 883 (1925) [FAA].

Supra note 97.

El Mundo Broadcasting Corp v United Steel Workers of America, $116 \mathrm{~F}$ (3d) 7 (1st Cir 1997) (under the FAA); Hall Steel Co v Metallloyd Ltd, 492 F Supp (2d) 215 (ED Mich 2007) (under the New York Convention). 
The costs of arbitration can vary widely and there is no certainty on which process (arbitration versus courts) will ultimately be less expensive. ${ }^{104}$ As noted by David Wotherspoon,

[A]rbitrators and courts have maintained concurrent jurisdiction over some aspects of disputes referred to arbitration. This concurrent jurisdiction has at times forced the parties to commence parallel proceedings.... Inevitably, the existence of parallel proceedings has increased the time, cost and complexity of arbitration, thereby undermining the very benefits parties may have believed they were achieving. ${ }^{105}$

\section{ii. Choice of Arbitration Tribunal/Rules}

The tribunal chosen for dispute resolution will depend on the parties involved and the nature of the dispute. Many jurisdictions have local laws that govern arbitration, ${ }^{106}$ however parties often contract for the application of the rules of international institutions. The role of an arbitral institution in the arbitral process will differ from one institution to the other. The institution does not hear or decide the dispute, rather it organizes the administrative aspects of the arbitration and assists in certain procedural rules. ${ }^{107}$ There are many international arbitral institutions, and some of the most commonly recognized institutions include: (1) the International Court of Arbitration of the International Chamber of Commerce (ICC); (2) the London Court of International Arbitration (LCIA); (3) the International Centre for Dispute Resolution; and (4) ICSID (which is the common forum for investor-state disputes). Historically, these have been considered the most prominent institutions, with the ICC and the LCIA historically being the most commonly used for international oil and gas agreements. However, there are many other regional institutions including: the Inter-American Commercial Arbitration Commission, the Singapore International Arbitration Center, the German Institution of Arbitration, the Stockholm Chamber of Commerce, the Hong Kong International Arbitration Centre, and the China International Economic Trade Arbitration Commission. International agreements often refer to the "UNCITRAL Rules" (developed by the United Nations Commission on International Trade Law), which have been widely used in both general commercial transactions and arbitrations between states and individuals. Although there is no administering institution under the UNCITRAL Rules, parties commonly designate an "appointing authority" to appoint the arbitrator(s) if the system of party appointments breaks down, and to deal with any challenges to the arbitrators. $^{108}$

See Lexpert, "Energy," supra note 80.

Wotherspoon, supra note 99.

See e.g. Alberta's International Commercial Arbitration Act, RSA 2000, c I-5.

Peter Sherwin, Ana Vermal \& Elizabeth Figueira, "The Decision to Arbitrate" in Proskauer on International Litigation and Arbitration: Managing, Resolving and Avoiding Cross-Border Business or Regulatory Disputes (New York: Proskauer Rose LLP, 2011) ch 19, III.B.1, online: Proskauer Law $<$ www.proskauerguide.com/arbitration/19/III>.

Many arbitral institutions will serve as an appointing authority under the UNCITRAL Rules for a fee. If no appointing authority is designated and the system of party appointments breaks down, the Secretary General of the Permanent Court of Arbitration in The Hague (a body created by the 1899 Hague Convention for the Pacific Settlement of International Disputes) will appoint an appointing authority. 


\section{iii. Insurance}

Political risk insurance may be available, and the costs and benefits of the coverage will need to be assessed. Political risk insurance is very expensive, as it is very difficult for the insurer or the insured to mitigate those types of losses. Often when reviewed, it is determined that such insurance offers limited protection against political risk as "underwriters price their products extremely high, offer very short-term coverage or don't offer any coverage at all."109 However, when political risk insurance is obtained from a government organization (such as Export Development Canada) there is an added benefit that the issuing government may intervene to address the loss. This can be helpful as long as the company and the government are aligned in each of their expectations arising out of the loss. It is important that the terms, conditions, and limitations of any political risk insurance be reviewed by experienced outside counsel and insurance experts.

\section{iv. Canadian Government}

The Canadian government (in particular, embassies, consulates, and the DFATD) is an important source of intelligence regarding the political situation in the emerging market, as well as a source of influence under the right circumstances. Resorting to political pressure from the Canadian government needs to be done carefully to avoid the perception of meddling or disenfranchising local governments and officials. ${ }^{110}$ Further, as discussed in Part IV.D (Human Rights and Community Relations), the Canadian government has announced it will restrict access to its "economic diplomacy" measures for those Canadian companies that fail to align with Canada's recently implemented Enhanced CSR Strategy.

\section{v. Industry Groups and Trade Associations}

Industry groups can be a valuable resource with respect to an investment in an emerging markets and companies may wish to join such an association or help to form one in emerging markets where the business is in its infancy. In-country industry groups often share information related to a number of important factors. In addition, trade associations can offer a useful vehicle for companies to act collectively to achieve common goals and develop transparent and consistent market practices in an emerging market. The association can help promote a positive reputation and local relationships by liaising with oil and gas companies, community members, governments, and other stakeholders. It can help improve the operating standards of the industry, while ensuring that companies are engaging with the government and communities in a unified fashion on certain subjects. ${ }^{111}$ The association would need to

Henisz \& Zelner, supra note 68 at 91.

Ibid at 93 .

The mandates for such an industry trade association in an emerging market may include: (1) working with the host government to build a regulatory regime that is clear and understood by industry, participating in the legislative process and providing input on regulatory developments; (2) commitments for the development of best practices and standards for the energy industry and promoting health, safety, and environmental excellence in the industry; (3) balancing efficient extraction of resources and development in a sustainable and socially responsible manner; (4) engaging with local communities and residents in an open and honest manner and responding promptly to the concerns of local stakeholders; (5) developing security strategies and common principles for the use of security forces and security protocols; (6) working with other industry members in the event of an emergency to assist with evacuations, medical support, and other emergency services; (7) promoting awareness of and compliance with anti-corruption and other laws, and advocating for enhanced transparency and accountability in government and business; and (8) accumulating relevant local laws and translations. 
ensure that it does not participate in wage fixing, price fixing, or anti-competitive behaviours, and would generally not act as a forum to resolve conflicts between companies or between industry and the government.

\section{CORRUPTION RISK}

\section{RISK OVERVIEW}

Another common and high-profile risk presented in emerging markets is the risk of corruption. Oil and gas companies in emerging markets encounter frequent interaction with foreign government officials at all stages of their projects. ${ }^{112}$ It has long been recognized that corrupt activities have been broadly utilized to supplement foreign officials' income in certain impoverished countries. ${ }^{113}$ When investing in an emerging market, the corruption risk must be assessed, and thorough due diligence must be conducted in respect of acquisitions, partners, agents, and the general business environment. Transparency International publishes a "Corruption Perceptions Index" each year ranking the perceived level of corruption in countries worldwide, where a poor score on the index "is likely a sign of widespread bribery, lack of punishment for corruption and public institutions that don't respond to citizens' needs." 114

While historically Canada did not have a strong track record of prosecuting bribery, Canada has improved its ranking with Transparency International to the tenth best ranking in 2014, in part due to increased enforcement activity with respect to both companies and individuals under the Corruption of Foreign Public Officials Act. ${ }^{115}$ Fundamentally, the CFPOA prohibits giving a "reward, advantage or benefit of any kind" to a "foreign public official" either "as consideration for an act or omission by the official in connection with the performance of the official's duties," or "to induce the official to use his or her position to influence any acts or decisions of the foreign state," including any department, branch or

Private bribery, not involving government officials, must also be managed and recognized as a crime. Most corporate codes of conduct and policies expressly prohibit private bribery and kick-backs. These are also recognized as a crime (Canada's "secret commissions offense") under the Criminal Code, RSC 1985, c C-46, s 426.

113 US Department of Commerce International Trade Administration, Business Ethics: A Manual for Managing A Responsible Business Enterprise in Emerging Market Economies (Washington, DC: US Department of Commerce International Trade Administration, 2004) at 7, online: $<$ ita.doc.gov/good governanceadobe/bem manual.pdf $>$.

114 Transparency International, "Corruption Perceptions Index 2014: Results" (2014), online: $<$ https://www. transparency.org/cpi2014/results>.

115 SC 1998, c 34 [CFPOA]. According to DFATD's website, there have been four convictions under the CFPOA: see $R v$ Watts, [2005] AJ No $568(\mathrm{QL})(\mathrm{QB})$ (known as the Hydro Kleen case); $R v$ Griffiths Energy International, [2013] AJ No 412 (QL) (QB) [Griffiths]; R v Niko Resources Ltd (2011), 101 WCB (2d) 118 (Alta QB), online: Canadian Bar Association < https://www.cba.org/ABC/ladefense/Pdf/ Niko\%20Probation\%20Order.pdf $>$ [NIKO Probation Order]; $R$ v Karigar, 2013 ONSC 5199, 2013 ONSC 5199 (CanLII)) [Karigar 2013]). There are currently 36 ongoing investigations. The investigations are now conducted under the RCMP Federal Policing Support Services, Federal Coordination Centre, and the RCMP's International Anti-Corruption Unit, which currently has two seven-person teams based in Ottawa and Calgary. Nazir Karigar, a paid agent for Cryptometrics Canada, was the first individual convicted under the CFPOA, related to his bribery of Air India officials and the Minister of Civil Aviation, and he was sentenced to three years' imprisonment: see $R v$ Karigar, 2014 ONSC 3093, 2014 ONSC 3093 (CanLII). In 2012, two individuals, Ramesh Shah and Mohammed Ismail, were arrested and charged in connection with the SNC Lavalin case. It was recently announced that SNC Lavalin was charged with corruption and fraud under the CFPOA in respect to money paid to public officials in Libya allegedly to influence government decisions: see W Michael Osborne, "SNCLavalin Charged With Foreign Corruption Offences" (20 February 2015), online: Litigator <www.the litigator.ca/2015/02/snc-lavalin-charged-with-foreign-corruption-offences/>. 
agency of the foreign state. ${ }^{116}$ In 2013, the CFPOA was amended to strengthen the jurisdiction clauses, the CFPOA's punitive measures, and to remove the allowances for "facilitation payments." 117 The following section describes some of the ways in which governments and companies are trying to address global corruption issues and practical guidance for anti-corruption measures with respect to business practices in emerging markets.

\section{Mitigation STRATEgIES}

\section{a. Understanding the Applicable Anti-Corruption Legislation}

A fundamental measure that must be taken by any company operating in an emerging market is to ensure there is a clear understanding of the requirements of anti-corruption legislation that applies to the company, its officers, directors, and personnel, both within the home jurisdiction and elsewhere. In addition to reviewing the applicable Canadian, American, British, or other statutes that might apply, the anti-corruption legislation and criminal codes in the host state must be reviewed, as it is very common that there will be anti-bribery provisions, often with specific requirements and penalties. While these provisions may or may not be widely enforced, and practices may vary, companies should require strict compliance with those local laws (as well as the CFPOA and other applicable anti-corruption legislation).

Blatant examples of corruption are often relatively easy to identify. However, in other situations, applying the mandates of the CFPOA and other applicable bribery statutes to particular fact situations presents a myriad of questions and there is a lack of case law and guidance around investigations of corrupt practices. ${ }^{118}$ Trying to advise clients on nuanced fact patterns and the application of the laws to particular questions can be very challenging, even for the most ethical and conservative companies. It can be very time-consuming to research and evaluate the legal analysis, only to end up with a vague and qualified response. As noted by Paul Blyschak:

See Bill S-14, An Act to Amend the Corruption of Foreign Public Officials Act, 1st Sess, 41st Parl, 2013 (assented to 19 June 2013) [Bill S-14]. Bill S-14 was enacted on 18 June 2013 and introduced amendments including (1) introducing nationality jurisdiction under the Act, creating an offence for any act or omission committed outside Canada by any Canadian citizen, permanent resident, or corporate person organized under the laws of Canada, which, if it had been committed in Canada, would violate the Act; (2) increasing the maximum sentence of imprisonment for offences under the Act from 5 to 14 years; (3) a books and records offence, which created an offence for failure to maintain accurate records, or for creating fraudulent records; and (4) removing the exceptions related to facilitation payments (which is not yet in effect). 
Uncertain application of anti-corruption law can easily result in managerial inefficiencies, increased compliance costs, and the misallocation of resources. It can also create an unnecessary chill on international transactions, decreased Canadian involvement in emerging markets, and decreased competition in those economies that foreign anti-corruption law is partly intended to benefit. ${ }^{119}$

Due to the uncertainty regarding how liability may be imposed in various contexts under the CFPOA, practitioners in this area often investigate the treatment by the US Department of Justice in similar situations and refer to guidance under the US Foreign Corrupt Practices Act. ${ }^{120}$ The company should engage experienced and reliable compliance officers and legal advisors with expertise on corruption matters and the detection and prevention of corruption in emerging markets. A methodical approach to considering the application of these laws and corporate policies (which are discussed below) to various fact patterns will need to be developed, so these questions and concerns are addressed in a legal, ethical, and efficient manner.

\section{b. Transparency Initiatives and the New Extractive Sector Transparency Measures Act}

To supplement legislation targeted at fighting corruption, voluntary and mandatory transparency initiatives have been introduced, and the status and application of these initiatives should be investigated when assessing the corruption risk presented in a country or with a particular party. For example, the country's status with the Extractive Industries Transparency Initiative (EITI) should be investigated (as a "Candidate" or "Compliant" country), ${ }^{121}$ and EITI reports that have been filed by the host country can be reviewed to confirm that payments attributed to the party and the host government contract are consistent with such party's records. Companies may also elect to become a "Supporting Company" under EITI, and adopt the associated reporting protocols and practices. ${ }^{122}$

Blyschak, ibid at 705. See also "The anti-bribery business," The Economist (9 May 2015), online: $<$ www.economist.com/news/business/21650557-enforcement-laws-against-corporate-bribery-increasesthere-are-risks-it-may-go $>$ (discussing the time and resource intensive nature of bribery investigations, the legal process, and exorbitant costs).

Pub L No 95-213, 91 Stat 1494 (1977) (codified as amended at 15 USC 78) at $\$ 78 d d-1$ [FCPA]. See also the guidance provided by the US Department of Justice in regards to the FCPA, including the Department of Justice \& Securities and Exchange Commission, A Resource Guide to the US Foreign Corrupt Practices Act (Washington, DC: Department of Justice, 2012), online: Securities and Exchange Commission <www.sec.gov/spotlight/fcpa/fcpa-resource-guide.pdf $>$ [FCPA Resource Guide].

EITI "is a global standard to promote open and accountable management of natural resources" (Extractive Industries Transparency Initiative, "What is the EITI?," online: <eiti.org/eiti>). See also Extractive Industries Transparency Initiative, "EITI Countries," online: $<$ https://eiti.org/countries $>$. To be an "EITI Country," a set of financial reporting standards must be effectively implemented and used by both the government and extractive industry companies active in the country regarding payments made and received. Companies may also become "supporting companies" through an application process and by paying annual fees.

122 Extractive Industries Transparency Initiative, "Company Support of the EITI," online: < eiti.org/ supporters/companies/howto>. 
While EITI is a voluntary initiative that has received increased endorsement and attention in recent years, many countries are in the process of adopting mandatory legislative requirements dealing with extractive industry transparency. ${ }^{123}$ In Canada, the ESTMA, ${ }^{124}$ received royal assent on 16 December 2014 and was proclaimed into force on 1 June 2015, which means that reporting under the ESTMA will need to be made in 2017 in respect of payments made during 2016 and afterwards. ${ }^{125}$ The Canadian government has articulated that the purpose of the ESTMA is to "implement Canada's international commitments to participate in the fight against corruption through the implementation of measures applicable to the extractive sector, including measures that enhance transparency and measures that impose reporting obligations with respect to payments made by entities. Those measures are designed to deter and detect corruption." $" 126$

The ESTMA contains broad reporting obligations for payments made by oil and gas and mining companies to governments (Canadian or foreign governments) and significant penalties for non-compliant companies and their directors and officers. A summary of the key components of the ESTMA is attached in Appendix B. The regulations for this Act have yet to be released.

These voluntary and mandatory transparency initiatives should, over time, reduce the prevalent risk of corruption in emerging markets. Companies must dedicate resources and prepare to meet the reporting requirements under the new reporting rules. Many companies and industry groups have advocated the importance of harmonizing the Canadian, American, European, and other legislation so as to reduce the reporting burden for entities that must report in multiple jurisdictions. Compliance with the ESTMA and other comparable legislation in other countries is expected to present challenges to oil and gas companies as

See Dodd-Frank Wall Street Reform and Consumer Protection Act, Pub L No 111-203, 124 Stat 1376 (2010), s 1504. Though the reporting requirements created under this provision in 2012 were successfully challenged by a case brought by the American Petroleum Institute in 2013, new requirements which fulfill the original intention of the section are expected to be proposed by the Securities Exchange Commission. However, at the time of writing, they have yet to be proposed. Also see section 10 of the 2013 European Accounting Directive: EC, Directive 2013/34/EU of the European Parliament and of the Council of 26 June 2013 on the annual financial statements, consolidated financial statements and related reports of certain types of undertakings, amending Directive 2006/43/EC of the European Parliament and of the Council and repealing Council Directives 78/660/EEC and 83/349/EEC, [2013] OJ, L 182/19, online: EUR-Lex <eur-lex.europa.eu/legal-content/ $\mathrm{EN} / \mathrm{TXT} / \mathrm{PDF} /$ ?uri=CELEX:32013L0034\&from=EN $>$, which requires each member country of the European Union to create a legislative reporting structure, with all member states being required to enact legislation by July 2015. Great Britain was the first member state to introduce their reporting requirements on 1 December 2014: The Reports on Payments to Governments Regulations 2014, SI 2014/3209, online: UK Ministry of Justice <www.legislation.gov.uk/uksi/2014/3209/pdfs/uksi_2014 3209 en.pdf $>$. France's legislation came into force on 1 January 2015 (Loi $n^{\circ} 2014-1662 \bar{d} u 30$ décembre 2014 portant diverses dispositions d'adaptation de la législation au droit de l'Union européenne en matière économique et financière, JO, 31 December 2014, 23238, online: Legifrance $<$ www.legifrance.gouv.fr/affichTexte.do? cidTexte=JORFTEXT000029999826\&categorieLien=id $>$ ). Outside of the European Union, Norway also adopted similar legislation in late 2013 (Forskrift om landfor-land rapportering, Fastsatt av Finansdepartementet 20. desember 2013 med hjemmel i lov 17. juli 1998 om årsregnskap § 3-3 c syvende ledd og lov 29. juni 2007 nr. 75 om verdipapirhandel $\S 5-5$ a fjerde led, as translated into English by Publish What you Pay Norway, "Norwegian Regulations Concerning Country-by-Country Reporting," online: <www.publishwhatyoupay.no/en/node/16414>). ESTMA, supra note 5.

125 Government of Canada, "Establishing Mandatory Reporting Standards for the Extractive Sector" 2014), online: $<$ open.canada.ca/sites/default/files/consultation paper spring 2014.pdf $>$. The requirements for reporting under the ESTMA will apply to payments made to A boriginal governments in Canada starting two years after the ESTMA comes into force (which means reporting would be required for Aboriginal government payments made after 1 June 2017). ESTMA, ibid, s 29. 
they grapple with the compliance issues in multiple jurisdictions, as well as potential conflicts with host governments regarding disclosure and confidentiality restrictions in host government contracts and under local laws. ${ }^{127}$

\section{c. Anti-Corruption Policies and Training}

The United Kingdom Ministry of Justice has outlined six principles for anti-corruption programs: (1) top level commitments; (2) risk assessment; (3) proportionate procedures; (4) due diligence; (5) communication and training; and (6) monitoring and review. ${ }^{128}$ In the Probation Order for Niko Resources Ltd., the Alberta Court of Queen's Bench outlined a compliance program and internal controls to be followed by the company. ${ }^{129}$ Corporate policies should include the following elements:

- a tone from the top for strict compliance with the law and ethical business conduct, with zero tolerance for bribes and severe consequences for violations;

- an explanation of the key anti-corruption provisions and requirements, including no facilitation payments, and a clear explanation of the limited exceptions when certain types of payments or expenditures are permitted;

- internal controls and enforced expense policies, including pre-approval and notification requirements for specified activities, and sensitive areas such as gifts and entertainment;

- $\quad$ clear due diligence expectations and best practices for engaging third party agents and completing transactions;

- $\quad$ transparent record-keeping;

- $\quad$ reporting and investigations, including whistleblower hotlines and review protocols; and

- clear delineation of the responsibilities of the compliance officer, management, audit and risk committees, and the board of directors. ${ }^{130}$

Transparency International Canada Inc. has published an anti-bribery checklist aligned to the requirements of the CFPOA as well as other useful resources that companies can

American Petroleum Institute v US Securities and Exchange Commission, 714 F (3d) 1329 (DC Cir 2013).

UK, Ministry of Justice, Guidance About Procedures Which Relevant Commercial Organisations Can Put Into Place To Prevent Persons Associated With Them From Bribing (London: Her Majesty's Stationery Office, 2010), online: UK, Ministry of Justice <www.justice.gov.uk/downloads/legislation/ bribery-act-2010-guidance.pdf> [UK Ministry of Justice Guidance].

NIKO Resources Ltd, a Calgary-based resource company, pled guilty to bribery under the CFPOA in 2011 relating to payments made to the Bangladesh Energy Minister (in the form of providing a vehicle, as well as paying certain travel costs of the Minister). The Probation Order issued by the Court of Queen's bench listed specific compliance measures NIKO was required to implement, which are reflective of the principles outlined by the UK Minister of Justice: see NIKO Probation Order, supra note 115 and the transcript of proceedings from the Court of Queen's Bench of Alberta, Calgary Courts Centre, $R v$ Niko Resources Ltd, E-File No: CCQ11 NIKORESOURCES, 24 June 2011. See UK Ministry of Justice Guidance, supra note 128; NIKO Probation Order, ibid. 
reference when corruption situations arise. ${ }^{131}$ The policies and practices should be customized based on risk assessments and the requirements should be proportional and tailored to the risks presented in particular environments. The approach to corruption due diligence and anti-corruption practices in low risk countries is going to vary vastly from the heightened protections a company may require in high-risk regions. In certain countries, it is common to use a third-party agent to help a company become established in a country, while in other regions, it is very rare. The areas of particular sensitivity should be reviewed carefully, and areas of high-risk exposure to corruption often include: (1) the granting, extending or amending of contracts; (2) development and regulatory approvals (or waivers); (3) environmental or safety incidents or other incidents of non-compliance with local laws; (4) import/export activities; (5) meeting fees, government training and per diems; (6) labour and workforce authorizations; and (7) interaction with security forces.

The company must provide thorough and recurring anti-corruption training to personnel, agents and contractors, and associated entities (where appropriate) on the policies and anti-corruption standards, reporting and approval procedures, and preventative measures tailored to the location. The nature and frequency of the training will vary depending on the role of the individual (or associated entity), the location, and the likelihood that such person or entity will confront corruption issues and have interaction with government officials regarding matters where corruption is common. There should be annual requirements whereby the training is refreshed and personnel and relevant contractors review, acknowledge, and agree to the terms of the relevant policies and codes of conduct. As well, when management or personnel who have interacted with government officials leave the company (or cease to provide services to the company), exit interviews should be conducted to ensure those individuals were not aware of any situations that had not previously been reported or addressed by the company.

\section{d. Defining Foreign Public Officials}

In certain emerging markets, companies often rely on services from those individuals with experience, expertise, and good reputations and relationships with government. A company will need to understand which individuals are considered foreign public officials. The terms "foreign public official" (under the CFPOA) or "foreign official" (under the FCPA) are broadly defined to include persons "who perform public duties or functions for a foreign state" or are "acting in an official capacity for or on behalf of [governments]." 132 However, there is little jurisprudence on the definition of "foreign public official" under the CFPOA or "foreign official" under the FCPA. The determination of the person's role within the government may not be clear and the lines between a private versus a public role may be blurred. In determining whether a person is a foreign official and how the legislation applies to government instrumentalities, a fact-specific analysis is required that turns on the

See Transparency International Canada, Anti-Corruption Compliance Checklist, 3rd ed (Toronto: Transparency International Canada, 2014), online: <www.transparency.ca/wp-content/uploads/2014/ 09/2014-TI-Canada Anti-Corruption_Compliance_Checklist-Third_Edition-20140506.pdf $>$. See also Transparency International, Resisting Extortion and Solicitation in International Transactions: A Company Tool for Employee Training (Berlin: Transparency International, 2011), online: < files. transparency.org/content/download/242/972/file/2001_RESIST_EN.pdf $>$ [Resist] (providing examples of responses to various corruption related scenarios and payment requests). 
individual's or instrumentality's ownership, influence or control, status, and function. ${ }^{133}$ While in some cases a person's or instrumentality's characterization is obvious, in the case of partially state-owned enterprises, former government officials, family members of officials, and village and tribal chiefs, these questions can be more difficult and will require a careful analysis of the individual's role and responsibilities, the organization of the particular government, the host government constitution, and laws describing those roles and authority within government (in addition to the type of payment or compensation being sought and its purpose). ${ }^{134}$ Some of these questions can be challenging, particularly in countries where there is a small educated class with interlocking relationships and familial ties, as well as frequent movements in government positions and roles.

\section{e. Payments Permitted or Required by Law}

and Responses to Payment Requests

It is common in some emerging markets for governments and government officials to request payments under a variety of circumstances, some of which may be clearly contemplated under a host government contract and local laws, and others which are not. These requests will need to be evaluated in the context of applicable anti-corruption laws. The CFPOA includes a "savings" provision that allows payments to be made that are "permitted or required under the laws of the foreign state or public international organization." $" 135$ When faced with a request for a payment from a government official, the company should inquire where the payment is required under the host government contract or the laws of the host state. Vigilance will be required to ensure that, when an official purports that a payment is required by law, it must be a validly authorized written law adopted through the proper legislative or executive channels, which will involve reliable local law expertise and analysis. Valid laws must generally be passed by the legislature or some form of presidential decree. Other forms of ministerial or government orders, while they may look official, may not be valid and may not qualify for the exception. Generally, payments should be made to the host country's public treasury, not other government divisions or ministries, unless expressly authorized under valid local law.

To the extent a company determines a payment is invalid and cannot be made, the company should be firm in its response and explain the basis for the prohibition under Canadian and other applicable laws, and that legal advice has been provided from legal counsel. The company can explain the severe consequences of breaches of laws and corporate policies, the strict reporting and disclosure requirements for payments made to government officials, and the increased enforcement activities in recent years. ${ }^{136}$

FCPA Resource Guide, supra note 120 at 20. See also US Department of Justice Criminal Division, Foreign Corrupt Practices Act Review (Washington, DC: Department of Justice, 2012) at 5, online: $<$ www.justice.gov/sites/default/files/criminal-fraud/legacy/2012/09/27/1201.pdf $>$ (assessing whether members of the royal family are foreign officials).

Stuart H Deming, "Canada's Corruption of Foreign Public Officials Act and Secret Commissions Offense" (2014) 29:2 Am U Intl L Rev 369; Roger Witten, Kimberly Parker \& Jay Holtmeier, "Meaning of 'Foreign Official' Under the FCPA" LexisNexis Legal Newsroom (26 April 2012), online: $<$ www.lexisnexis.com/legalnewsroom/corporate/b/fcpa-compliance/archive/2012/04/26/meaning-ofquot-foreign-official-quot-under-the-fcpa.aspx $>$. See Karigar 2013, supra note 115 (finding that Air India is a corporation owned and controlled by the Government of India and the officials were "Foreign Public Officials" under the CFPOA).

136 See also Resist, supra note 131 (for various scenarios and recommended responses from Transparency International). 


\section{f. Gifts and Entertainment; Training of Government Officials}

Gifts and entertainment of government officials is a sensitive area that requires appropriate judgment and decision-making. ${ }^{137}$ In some jurisdictions, this is a common practice, and in others it would be very rare to entertain or present gifts to government officials. The anti-corruption program should clearly spell out the notification and approval requirements for these expenditures and should ensure that no cash payments or cash gifts are made, that the activities will not be construed as a bribe or kickback, that the gift and entertainment is nominal in amount and infrequent in nature, and that the entertainment or gift is an accepted, legal, and customary business practice in the local jurisdiction. With respect to training government officials, there are allowances under the CFPOA for reasonable expenditures incurred related to promotion of the company's products or services, or execution or performance of a contract between the company and the foreign government. ${ }^{138}$ The interpretation of those provisions to particular facts will require careful analysis. The company should also follow best practices associated with these types of expenditures, including directly paying vendors (airlines, hotels, restaurants), avoiding cash payments, and ensuring that expenditures are reasonable and not excessive in nature. ${ }^{139}$

\section{g. Retention of Third Parties}

Retaining the services of a third party, including an agent, consultant, contractor, joint venture partner, or other representative, can raise compliance issues and many corruption charges have related to the use of third party agents. ${ }^{140}$ This will be one of the first areas targeted by corruption due diligence inquiries in financings, listing applications and transactions. There should be stringent due diligence protocols and approval requirements in respect of the engagement of agents or consultants who interact with foreign public officials (for example, requiring approval from the compliance officer or the chairman of the audit committee or risk management committee). The due diligence practices should include investigation of a person or entity's reputation in the community, a business background check, inquiries with Canadian governmental agencies (for example, DFATD, Canadian government embassies, consulates, or foreign trade agencies), and inquiries with other industry participants. There are a number of third party service providers (accounting firms and other professional service firms) who specialize in these types of investigative searches and due diligence exercises, with a wide range of costs depending on the degree of investigation to be undertaken and the location. Any red flags or warning signs that arise during due diligence should be carefully investigated until resolved in a satisfactory manner. ${ }^{141}$

See NIKO Probation Order, supra note 115.

CFPOA, supra note 115, s 3(3)(b).

See NIKO Probation Order, supra note 115.

See Griffiths, supra note 115. See also the ongoing developments surrounding Viktor Kozeny: David Glovin, "Bourke Convicted of Bribery in Kozeny's Azerbaijan Oil Deal," Bloomberg (11 July 2009), online: <www.bloomberg.com/apps/news?pid=newsarchive\&sid=aXO.vHLdvbcM>.

Commonly recognized warning signs that are included in most corporate policies and should be considered as part of any due diligence include: (1) the third party has current business, family or some other close personal relationship with a foreign public official or was recently a foreign public official; (2) a foreign public official recommends or insists on the use of a certain business partner; (3) the third party refuses to agree to anti-corruption contractual terms, uses a shell company or other unorthodox corporate structure, insists on unusual or suspicious contracting procedures, refuses to divulge the identity of its owners, or requests that its agreement be backdated or altered in some way to falsify information; (4) the third party requests donations to individuals, charities or political parties; (5) the 
Third party agents should be engaged only when they are properly qualified for clearly defined services, and written agreements with the agents should include customary protective provisions (including anti-corruption related representations, compliance covenants, termination rights, and audit rights). Payments should be reasonable in amount, accompanied by detailed invoices describing the services, should be made to accounts in the local jurisdiction (not offshore), and the parties should retain proper records of the payments. Third party contractors should be provided with a copy of the company's policies that govern their conduct (for example, an anti-corruption policy, code of conduct, and whistleblower policy), and they should receive an orientation and training on the requirements. The degree of due diligence, training and compliance considerations, and the terms of the written agreement will depend on the contractor's role and services and the nature of interaction with government officials. Companies will need to investigate the beneficial ownership of entities with whom they do business to ensure they know who they are partnering with and that there are not public officials to whom funds are being channeled through an illicit vehicle.

\section{h. Charitable Donations}

Companies operating in emerging markets are viewed as a source for community investment and charitable donations. However, charities are used at times as a facade to filter improper payments to government officials. It will be important to make the appropriate inquiries and conduct due diligence to decipher the use of funds for legitimate purposes and determine who is involved in the charity. Proper documentation should be obtained to reflect the understanding regarding the donation and the use of funds, as well as appropriate representations and restrictions to provide assurances from an anti-corruption standpoint. The agreements will need to be communicated and translated into the appropriate language to ensure that the requirements are explained and understood.

\section{i. Reporting Protocols, Whistleblower Policies, and Hotlines}

Corporate anti-corruption policies should include reporting protocols to a compliance officer, with further reporting to the board of directors (or one of its committees) as required in the case of questions or concerns. It is important that the compliance officer has the appropriate level of independence, authority, and resources to perform his or her role effectively, as well as a direct and unfiltered reporting line to an independent member of the board (or committee thereof). To properly raise the questions that need to be flagged under the policy, boards and senior management should implement a system of periodic inquiries to be made to the individuals working with government officials or authorizing payments to have them respond to specific questions regarding any payments, government donations, requests for payments, or other areas that are covered under the corporate policy. Those inquiries must be properly translated and reported directly to the compliance officer and a supervisor on a confidential basis (without being filtered or modified). Individuals must be

third party has a poor reputation or has faced allegations of bribes, kickbacks, fraud or other wrongdoing or has poor or non-existent third-party references; (6) the third party does not have an office, staff, or qualifications adequate to perform the required services; or (7) an expense/payment request by the third party is unusual, is not supported by adequate documentation, is unusually large or disproportionate to products to be acquired, does not match the terms of a governing agreement, involves the use of cash or an off-the-books account, or is in a jurisdiction outside the country in which services are provided or to be provided: see discussion on corporate liability respecting third party agents in Blyschak, supra note 28 at $672-84$. 
required to comply with the appropriate reporting regimes within the company, as set out in the company's code of conduct, anti-corruption policy, or whistleblower policy.

Whistleblower hotlines should be properly established and tested to ensure the language abilities and translation services are coordinated and functioning. They must be accompanied by proper training for employees on the use of the hotline and how the information will be used and protected. In many cultures, it would be very unusual to expect a subordinate to challenge the activities of his or her superior, and it may be difficult to expect an employee to report misconduct of someone in his tribe or ethnic group. Hotlines must be set up to allow for confidential and anonymous reporting of violations, and they must be coupled with a "no retaliation" policy.

\section{j. Lawyer's Obligations under the Rules of Professional Conduct}

Lawyers also need to understand their obligations under the Law Society Rules of Professional Conduct that may arise under certain circumstances. Those rules emphasize that the client is the organization, not a particular individual, and impose client reporting obligations on a lawyer who is acting in a matter where the lawyer knows that the organization has "acted, is acting or intends to act fraudulently, criminally or illegally." In such case, the lawyer must:

(a) advise the person from whom the lawyer takes instructions and the chief legal officer, or both ... that the conduct is or would be fraudulent, criminal or illegal and should be stopped;

(b) if necessary ... advise progressively the next highest persons or groups, including ultimately, the board of directors ... or the appropriate committee of the board, that the conduct is or would be fraudulent, criminal or illegal and should be stopped; and

(c) if the organization, despite the lawyer's advice, continues with or intends to pursue the unlawful conduct, withdraw from acting in the matter in accordance with [the Rules of Professional Conduct]. ${ }^{142}$

Lawyers must exercise caution when advising clients operating in or from emerging markets to avoid being inadvertently involved in corrupt or illegal activity. ${ }^{143}$

\section{HUMAN RightS AND COMMUNITY RELATIONS}

\section{RISK OVERVIEW}

The risk of human rights violations is prominent for natural resource companies operating in emerging markets, as these countries often suffer from significant poverty, unsophisticated laws and legal systems, and weak rule of law. These human rights abuses may violate local laws, but those local laws may not be enforced. Non-governmental organizations and public 
interest groups have become involved in efforts to assist indigenous and local people in their efforts to pursue legal remedies. Human rights violations have become highly publicized due to litigation claims commenced against North American resource companies with respect to alleged human rights abuses in developing countries where they or their subsidiaries operate. ${ }^{144}$ Recent examples include:

- In Choc v. Hudbay Minerals Inc., a claim was filed in Ontario alleging that certain deaths and assaults were committed at the Fenix Mining Project in Guatemala by security personnel hired by a subsidiary of Hudbay. The plaintiffs claimed two possible causes of action: (1) Hudbay's direct liability for negligence in failing to prevent harm to the plaintiffs through the actions of its subsidiary (namely, its negligent management of the Fenix security personnel); and (2) Hudbay's vicarious liability for the conduct of its subsidiary and its subsidiaries' personnel based on a piercing the corporate veil argument (discussed in Part IV.F- Extraterritorial Litigation and Piercing the Corporate Veil below). ${ }^{145}$

- In Araya v. Nevsun Resources Ltd, a claim was filed in British Columbia alleging international human rights abuses by a Canadian mining company in relation to the company's Bisha Mine in Eritrea. Based on the news reports, Nevsun is alleged to have known, or ought to have known, that slave labour was being used by the local contractors of the company. ${ }^{146}$

- In John Doe v. Exxon Mobil Corporation, villagers from Aceh, Indonesia filed a claim in the District of Columbia under the US Alien Tort Claims Act alleging human rights abuses were carried out by security forces hired by Exxon and that Exxon knew or ought to have known that such human rights violations were being committed. ${ }^{147}$

- In Presbyterian Church of Sudan v. Talisman Energy Inc., a claim was filed in New York under the US Alien Tort Claims Act on behalf of non-Muslim Sudanese villagers who alleged Talisman collaborated with the government of Sudan to commit human

Jonathan Horlick et al, "American and Canadian Civil Actions Alleging Human Rights Violations Abroad by Oil and Gas Companies" (2008) 45:3 Alta L Rev 653, referring to Talisman Energy (Sudan), Royal Dutch/Shell and Chevron (Nigeria), Occidental (Columbia), Unocal (Burma), and ExxonMobil (Indonesia)). Under the Alien Tort Statute, 28 USC $§ 1350$ (1948), foreign citizens can seek remedies within US courts for human rights violations conducted outside of the US. A notable case which may pose a challenge to future claims under this statute was Kiobel v Royal Dutch Petroleum Co, $133 \mathrm{~S} \mathrm{Ct}$ 1659 (2013), where the US Supreme Court ruled that the Alien Tort Statute does not create jurisdiction for a claim regarding a corporation's conduct occurring in the territory of a foreign nation. See Sean ED Fairhurst \& Zoë Thoms, "Post-Kiobel v. Royal Dutch Petroleum Co: Is Canada Poised to Become an Alternative Jurisdiction for Extraterritorial Human Rights Litigation?" (2014) 52:2 Alta L Rev 389 at 392. 
rights abuses, in part by building infrastructure for its oil production activities which was then used by the government to commit human rights abuses. ${ }^{148}$

As evidenced in the case summaries above, human rights actions often involve claims against parent corporations domiciled in developed countries, in relation to the actions of their subsidiaries operating in the countries where the alleged human rights abuses took place. Foreign plaintiffs must establish that Canadian courts have jurisdiction to hear the relevant claims (a "real and substantial connection" between the dispute and the Canadian jurisdiction), as well as overcome "forum non-conveniens" challenges that there is a more convenient forum in which the dispute should be heard. ${ }^{149}$ The challenge of successfully making a claim against a parent corporation or other entity within a corporate group is discussed further below under Part IV.F (Extraterritorial Litigation and Piercing the Corporate Veil).

Indigenous people claiming human rights violations and other negative impacts of oil and gas projects may also target the shareholders of companies as an audience to try to influence change. For example, in 2004, the chief of an indigenous tribe in Ecuador attended the shareholders meeting of Burlington Resources in order to request that the company stop its exploration efforts in the central and southern regions of Ecuador's rainforest. ${ }^{150}$ In a more recent example, in April 2015 the Association of Ethical Shareholders Germany filed a shareholders motion calling on BASF, a chemical corporation and a major customer of Lonmin, to share responsibility and ensure that victims were financially compensated by Lonmin in respect to the death of striking miners who died when police opened fire on the workers at a Lonmin-owned platinum mine in South Africa in 2012. ${ }^{151}$ Shareholder activism can be effective in convincing investor groups that the issues activists are addressing may pose financial, competitive, reputational, and legal risks to the targeted company and its shareholders. ${ }^{152}$ Shareholder activism can be utilized to encourage companies to adopt recognized international principles. For example, the American Federation of State, County and Municipal Employees Pension Plan has raised proposals at shareholder meetings for such companies such as Halliburton and Caterpillar, which would require such companies to comply with human rights due diligence as set out within the United Nations Guiding Principles on Business and Human Rights, discussed below. ${ }^{153}$

244 F Supp (2d) 289 (SDNY 2003). Although the Court did not find Talisman liable for the alleged human rights abuses, following the public outcry arising from the publicity of Talisman's operations in Sudan and the alleged human rights abuses, Talisman withdrew from its operations in Sudan in 2002. See Kyle Bakx, "Oil, politics and human rights: A look back at Talisman," CBC News (22 February 2015), online: <www.cbc.ca/news/business/ oil-politics-and-human-rights-a-look-back-at-talisman$1.2964715>$.

Fairhurst \& Thoms, supra note 144 at 405, citing Club Resorts Ltd v Van Breda, 2012 SCC 17, [2012] 1 SCR 572 at para 69.

Emily McAteer \& Simone Pulver, "The Corporate Boomerang: Shareholder Transnational Advocacy Networks Targeting Oil Companies in the Ecuadorian Amazon" (2009) 9:1 Global Environmental Politics 1 at 1 , online: MIT Press <www.mitpressjournals.org/doi/pdf/10.1162/glep.2009.9.1.1>.

Business \& Human Rights Resource Centre, "BASF challenged to share responsibility for the 2012 Marikana Massacre in So Africa" online: < business-humanrights.org/en/basf-challenged-to-shareresponsibility-for-the-2012-marikana-massacre-in-so-africa>.

Ibid.

Amol Mehra, "Respecting Human Rights: Shareholders Shift from Policy to Action" The Corporate Social Responsibility Newswire (22 April 2013), online: <www.csrwire.com/blog/posts/812-takingaction-to-respect-human-rights-shareholders-shift-from-policy-to-action>; Guiding Principles on Business and Human Rights: Implementing the United Nations "Protect, Respect and Remedy" Framework, UNHRC, 17th Sess, Annex, UN Doc A/HRC 17/31 (2011) 6 [UN Guiding Principles]. 


\section{Mitigation Strategies}

These risks and the recent legislative and policy changes in Canada, including the announcement of the Enhanced CSR Strategy, underscore the need for Canadian extractive sector companies operating abroad to focus on developing long-term community relations strategies in accordance with internationally accepted best practices. These strategies can be complex and difficult to manage on long-life projects in volatile environments. Companies must be careful to engage CSR experts experienced in the particular region who understand the operating environment and cultural and ethnic issues that may arise. It is crucial that, from the outset, a strategic and long-term approach be taken on community relations matters and the types of projects and commitments that are made during the life-span of the project.

\section{a. CSR Policies and Guidelines}

The implementation of strong CSR policies and guidelines is particularly important for corporations with operations in emerging markets to supplement the local standards of domestic legislation and mitigate operational and reputational risks. The Canadian government's recently implemented Enhanced CSR Strategy (discussed further in Appendix A) builds on the government's original CSR strategy announced in 2009 which was intended to provide CSR guidance and support to Canadian extractive sector companies working in developing countries. The Enhanced CSR Strategy aims to increase extractive sector companies' awareness and participation in CSR "best practices" by making the Canadian government's economic diplomacy conditional on a company's alignment with the Enhanced CSR Strategy. ${ }^{154}$ The Canadian government has stated it will withdraw trade commissioner and other support from companies that refuse to participate in the dispute resolution process administered by the Office of the CSR Counselor, or that are not "embodying CSR best practices." 155 In light of this, it is important that companies appropriately investigate and address CSR risks and the potential for human rights abuses in the jurisdictions in which they operate. This is particularly important in areas such as procurement, as the company must ensure that contractors who are selected to work on the company's operations (but are subject to less direct oversight from the company), do not engage in activities that violate human rights. As noted further below, this concern is particularly acute in the case of security contractors. Boards and senior management should constantly monitor these issues and implement a system of periodic inquiries to be made to appropriate individuals to raise questions and elicit information regarding the company's and its contractors' human rights practices and potential areas of concern.

\section{b. UN Guiding Principles}

One challenge for companies in implementing CSR policies and practices to align themselves with Enhanced CSR Strategy, is that the Enhanced CSR Strategy does not articulate how companies can develop practices that "embody CSR best practices." There are a plethora of international guidelines and principles that duplicate similar concepts, and sifting through the requirements and determining the manner in which they intersect can be 
daunting for those trying to implement various standards. ${ }^{156}$ The Canadian government's Enhanced CSR Strategy currently expects Canadian extractive companies to align their CSR practices with six different sets of international standards (the Endorsed Principles), all of which encompass broad social, environmental and human rights principles. ${ }^{157}$ The UN Guiding Principles, ${ }^{158}$ which were endorsed by the UN Human Rights Council in June 2011, are being recognized as the leading standards for broad application, as they capture key principles and incorporate important aspects of the other Endorsed Principles. According to the International Bar Association:

\footnotetext{
The [UN Guiding Principles] have become the authoritative point of convergence on business and human rights internationally. They articulate a global consensus that businesses throughout the world should respect human rights. Increasingly, they are reflected in national policy and law, corporate sustainability reporting frameworks and governance, stock exchange listing requirements, international standard-setting bodies, commercial and financial transactions, and in the public and judicial advocacy of civil society.... [B]ar associations and lawyers need to understand the [UN Guiding Principles] and address the implications they have for the practice of law. ${ }^{159}$
}

In developing policies and practices to address human rights risks and community engagement principles, the UN Guiding Principles provide a broad and flexible "Protect, Respect, and Remedy" framework to serve as the foundation for a CSR program that can be supplemented with the other applicable Endorsed Principles.

\section{c. Elements of a CSR Program}

The UN Guiding Principles state that, in order for a company to meets its human rights responsibilities, it must have policies and processes in place appropriate to the company's size and circumstances, including at a minimum: (1) a policy commitment to meet its responsibility to respect human rights; (2) a human rights due diligence process to identify, prevent, mitigate, and account for how it addresses its impact on human rights; and (3) processes to enable the remediation of any adverse human rights impacts it causes or to which it contributes. ${ }^{160}$

To be effective, a corporate policy commitment must: (1) be approved at the most senior level of the business enterprise; (2) be informed by relevant internal and/or external expertise; (3) stipulate the enterprise's human rights expectations of personnel, business

This article does not attempt to address all international standards which may be of use for corporations when developing CSR policies and practices, but rather focuses on those standards highlighted in the Enhanced CSR Strategy and specifically the UN Guiding Principles. Other standards which may be relevant to companies are those standards adopted by investment institutions that are used when assessing and managing environmental and social risks for projects, such as the Equator Principles and the Principles for Responsible Investment. See Equator Principles Association, The Equator Principles June 2013: A financial industry benchmark for determining, assessing and managing environmental and social risk in projects (4 June 2013), online: <www.equator-principles.com/resources/equator principles III.pdf $>$; Principles for Responsible Investment, "The Six Principles," online: UNPRI $<$ www.unpri.org/about-pri/the-six-principles/>. See Appendix B for a further description of the Endorsed Principles. Supra note 153.

International Bar Association, "IBA opens global public consultation on its draft business and human rights guidance" (17 December 2014), online: <www.ibanet.org/Article/Detail.aspx?ArticleUid= f906f28f-a2ee-4adc-a0a6-e5dc19032271>.

UN Guiding Principles, supra note 153 at 15. 
partners, and other parties; (4) be publicly available and communicated internally and externally; and (5) be reflected in operational policies and procedures necessary to embed it throughout the business enterprise, such as within its performance incentives for personnel or through its procurement practices. ${ }^{161}$ The UN Guiding Principles emphasize that business and human rights initiatives should be approached by multinational enterprise groups in their entirety and not simply on an entity-by-entity basis. ${ }^{162}$

The UN Guiding Principles recognize due diligence as a way in which corporations can "identify, prevent, mitigate, and account for how they address" the adverse impacts of their activities. ${ }^{163}$ The frequency of the due diligence process should be connected to the scope of a corporation's policies, such that diligence is ongoing, as necessary to regularly assess a corporation's evolving operations and transactions. ${ }^{164}$ The process of identifying operational impacts includes identifying stakeholders who may be affected by the proposed business activity and how the proposed business activity could potentially create an adverse impact on those identified stakeholders. ${ }^{165}$ This process should involve either internal and independent external CSR experts, as well as consultation with affected stakeholders. ${ }^{166}$

Once the actual and potential operational impacts have been identified through the due diligence process, internal procedures should be put in place to address the impacts identified. ${ }^{167}$ In addition, systems should be implemented which can track the effectiveness of CSR policies on practices. These systems should be based on appropriate qualitative and quantitative indicators and feedback from both internal and external sources, including affected stakeholders. ${ }^{168}$ Corporations need to ensure that they have appropriate remediation policies and procedures to effectively respond to adverse events. An operational-level grievance mechanism that is accessible by individuals and communities is an important remediation measure and plays an important role in the CSR feedback process for companies:

- $\quad$ First, they support the identification of adverse human rights impacts as a part of an enterprise's ongoing human rights due diligence. They do so by providing a channel for those directly impacted by the enterprise's operations to raise concerns.... By analyzing trends and patterns in complaints, business enterprises can also identify systemic problems and adapt their practices accordingly.

- Second, these mechanisms make it possible for grievances, once identified, to be addressed and for adverse impacts to be remediated early and directly by the business enterprise, thereby preventing harms from compounding and grievances from escalating. ${ }^{169}$

Companies will need to continually emphasize its commitment to its CSR initiatives and ensure that shareholders and investors understand how the company is managing its business

Ibid.

Virginia Harper Ho, "Of Enterprise Principles and Corporate Groups: Does Corporate Law Reach Human Rights?” (2013) 52:1 Colum J Transnat'l L 113 at 129.

UN Guiding Principles, supra note 153 at 15.

Ibid at $16-17$.

Ibid at 17 .

Ibid.

Ibid at 18 .

Ibid at 19

Ibid at 25 . 
in a socially responsible manner. Companies should publish detailed CSR reports and other disclosures regarding these programs and initiatives.

\section{d. United Nations Declaration on the Rights of Indigenous Peoples}

Another international standard receiving increasing attention internationally and domestically is the United Nations Declaration on the Rights of Indigenous Peoples. ${ }^{170}$ The UNDRIP recognizes and affirms the rights of Indigenous peoples as being equal to the rights of non-indigenous peoples, and while it is not legally binding, the UN has described the UNDRIP as "an important standard for the treatment of indigenous peoples ... [which] will undoubtedly be a significant tool towards eliminating human rights violations against the over 370 million indigenous people worldwide and assist them in combating discrimination and marginalization.",171

Indigenous rights which the UNDRIP recognizes include: (1) that indigenous peoples have the right not to be forcibly removed from their lands or territories and that "no relocation shall take place without the free, prior and informed consent of the indigenous peoples concerned and after agreement on just and fair compensation and, where possible, with the option of return"; ${ }^{172}$ and (2) that indigenous peoples have the "right to the lands, territories and resources which they have traditionally owned, occupied or otherwise used or acquired." ${ }^{173}$ While the UNDRIP focuses on the relationship between indigenous peoples and the governments of the states in which they live, companies should ensure the development of their CSR policies or projects within traditional lands and territories of indigenous peoples are consistent with the rights recognized under UNDRIP to ensure the company is operating in accordance with internationally recognized standards and mitigating the risk of conflict with local communities. The Business Reference Guide to the UN Declaration on the Rights of Indigenous Peoples, ${ }^{174}$ which was developed by the UN, highlights how indigenous peoples' rights should be assessed in line with the policies and processes recommended under the UN Guiding Principles. It provides guidance as to how human rights due diligence conducted under the UN Guiding Principles can be further tailored to assess the impact of business activities on indigenous people with respect to the land or territories where these activities are located.

United Nations Declaration on the Rights of Indigenous Peoples, GA Res 61/295, UNGAOR, 61st Sess, Supp No 49, UN Doc A/RES/61/295 (2007) art 10, online: United Nations <www.un.org/esa/socdev/ unpfii/documents/DRIPS_en.pdf> [UNDRIP]; Aboriginal Affairs and Northern Development Canada, "Canada's Statement of Support on the United Nations Declaration on the Rights of Indigenous Peoples" (12 November 2010), online: <www.aadnc-aandc.gc.ca/eng/1309374239861/1309374546 $142>$.

171 "Frequently asked Questions - Declaration on the Rights of Indigenous Peoples," online: United Nations $<$ www.un.org/esa/socdev/unpfii/documents/FAQsindigenousdeclaration.pdf $>$.

UNDRIP, supra note 170, art 10.

Ibid, art 26 .

United Nations Global Compact, A Business Reference Guide: United Nations Declaration on the Rights of Indigenous Peoples (New York: United Nations Global Compact, 2013), online: <https://www.un globalcompact.org/docs/issues_doc/human_rights/IndigenousPeoples/BusinessGuide.pdf $>$. 


\section{E. Security for the Project and the Use OF Security Forces}

\section{RISK OVERVIEW}

Security risks present themselves in many different forms and from many different actors. Control Risks Group defines security risk as "the likelihood of state or non-state actors engaging in actions that harm the financial, physical, and human assets of a company and the extent to which the state is willing and able to protect those assets." ${ }^{175}$ These risks can be more acute in areas where there are significant numbers of refugees or terrorist activities, and the risks can be posed by "political extremists, direct action groups, the security forces, foreign armies, insurgents, petty and organized criminals, protesters, workforces, local communities, indigenous groups, corrupt officials, business partners, and in-country company management and staff." 176 In many regions, there are vast numbers of tribes and landowners that may be affected by a particular project, all of which may have varying agendas and tolerance for development. With respect to travel and new country entry, the company should assess the travel and security risk for that location. ${ }^{177}$

Government forces or militia will generally provide some level of security over certain operations, but the scope and degree of the coverage will vary. Security forces are a critical element to protecting a company's assets and people. However, the use of security forces has been the source of many atrocities related to mining and oil and gas companies. As noted in the IFC Guidebook, "in unstable or conflict affected areas, companies should consider whether their use of security personnel will in fact create conflict or exacerbate existing tensions," and the timing and manner in which security personnel are introduced should be considered carefully. ${ }^{178}$

There have been several examples of claims against Canadian mining companies and their affiliates related to excessive use of force by private and government security forces, including in Hudbay Minerals discussed above, ${ }^{179}$ and others such as:

- Garcia v. Tahoe Resources Inc. - The 2014 civil claim was filed in the Supreme Court of British Columbia by a group of plaintiffs injured in an incident between security personnel and protestors at the Escobal Mine Project in San Rafael Las Flores, Guatemala. ${ }^{180}$ The plaintiffs allege that Tahoe is liable for the express or implicit authorization of excessive force by mine security personnel or was negligent in failing to prevent personnel from using excessive force. ${ }^{181}$

RiskMap, supra note 66 at 106 .

Ibid.

Ibid; Foreign Affairs, Trade and Development Canada, "Country travel advice and advisories," online: $<$ travel.gc.ca/travelling/advisories $>$.

IFC Guidebook, supra note 31 at 177.

Supra note 145 .

Vancouver S144726 (BCSC) (in progress). Notice of Civil Claim, filed on 18 June 2014 by Joe Fiorante, QC, Vancouver Registry, online: Canadian Centre for International Justice <www.ccij.ca/content/ uploads/2015/07/Tahoe-Notice-Civil-Claim.pdf $>$.

Ibid at 6-7. 
- Assoc canadienne contre l'impunité e Anvil Mining Ltd ${ }^{182}$ - A class action suit was brought in Quebec against Anvil on behalf of residents in the Democratic Republic of Congo (DRC) who suffered harm as a result of the actions of the armed forces of the DRC in October 2004. ${ }^{183}$ The plaintiffs alleged that Anvil provided logistical help to the armed forces of the DRC during a conflict between DRC forces and a Zambian revolutionary group attempting to stake a claim of independence. ${ }^{184}$

- Kesabo v African Barrick Gold Plc - A suit was brought in England in 2013 against Barrick on behalf of relatives of Tanzanian villagers that were killed in incidents near a mine owned by Barrick's subsidiary. The plaintiffs alleged that Barrick's subsidiary had failed to prevent the use of excessive force by police and security. ${ }^{185}$

\section{As noted in the IFC Guidebook:}

The risks associated with engaging workers to provide security for project property and personnel include risks presented by the background histories, level and quality of training of security workers, the level of force exercised and equipment provided or permitted, and relationships between security workers and Affected Communities.

$[\mathrm{P}]$ roportionate and effective use of security personnel may also be a way of contributing to security conditions for the local community. Having said this, companies must ensure that the risk identification process addresses potential adverse effects upon workers and local communities including tensions created by the presence of security personnel within the community, greater incidences of violent or gender based crime and abuses of power if security personnel are not appropriately screened, trained and supervised, and the circulation and potential theft of firearms and weapons. ${ }^{186}$

\section{Mitigation STRATEGIES}

In December 2000, the US and UK Governments announced the Voluntary Principles on Security and Human Rights (Voluntary Principles), ${ }^{187}$ which are considered to be the leading civil society principles guiding how companies can maintain the safety and security of their operations within an operating framework that ensures respect for human rights and fundamental freedoms. The Government of Canada is a participating country in the Voluntary Principles, and many non-governmental organizations and oil and gas companies

2012 QCCA 117, [2012] RJQ 153 [Anvil] [translated from original French into English by Westlaw Canada's unofficial translation].

Ibid at paras $16-20$.

Ibid at para 26. Ultimately, the Court of Appeal determined that there was not a sufficient connection to activities in the province of Quebec to allow the Quebec legal system to claim jurisdiction over the matter (ibid at paras 103-105).

[2013] EWHC 3198, [2013] 6 Costs LR 954 (QB) [African Barrick Gold Plc]. An undisclosed settlement in respect to this claim was paid to the plaintiffs in February 2015. See John Vidal, "British Gold Mining Firm Agrees Settlement over Deaths of Tanzanian Villagers," The Guardian (10 February 2015), online: <www.theguardian.com/environment/2015/feb/10/british-gold-mining-settlement-deathstanzanian-villagers>.

IFC Guidebook, supra note 31 at 176-77.

Voluntary Principles on Security and Human Rights, "What Are the Voluntary Principles?," online:

$<$ www.voluntaryprinciples.org/what-are-the-voluntary-principles/> [Voluntary Principles]. 
are participants. ${ }^{188}$ The Voluntary Principles contain three principal components to help guide companies: (1) principles on risk assessment; (2) interactions between companies and public security; and (3) interactions between companies and private security. ${ }^{189}$

Experienced security advisors must be employed to assess the security risks and develop the approach to protection of property and assets and security requirements. These individuals often have a military background and are trained to assess and evaluate the security risk and appropriate security measures to be undertaken by the company. It will be important that they can appropriately represent the company's values, while interacting well with the private security contractors and government security forces.

\section{a. Security Policy and Guidelines}

For companies that utilize public and private security forces in locations that present the risk of excess force and human rights violations, a security policy and guidelines should be implemented which adopt the Voluntary Principles and apply their standards to security arrangements with public security, private security, and contractors. The detailed guidelines and practices will need to be tailored to each location and situation in compliance with the general mandates under the Voluntary Principles. The effective implementation of these guidelines will require that the relevant security forces, whether public or private, also adopt or agree to adhere to the Voluntary Principles and the policy guidelines.

The specific guidelines adopted under the policy must encompass and take into account gender and ethnic issues and appropriate staffing and training must occur. For example, body searches must be conducted in an appropriate manner (including by a person of the same gender) to preserve the safety and dignity of the person under review. Appropriate training must include clear and consistent instructions regarding the objectives of such security forces' work and permissible actions that may be taken in pursuit of such objectives, including using the least amount of force as appropriate given the context. ${ }^{190}$

\section{b. Private Security Contractors}

Where security services are contracted out to private security contractors, companies should ensure that the governing contracts require compliance with the company's security policy and the Voluntary Principles, and appropriately highlight the company's expectations with respect to how security services are to be provided, without compromising the nature of the contractor relationship. In situations where both government security forces and private security contractors are involved in monitoring operations, the company should set appropriate limitations on the contractor's ability to contact or engage with government security forces without the prior consent of the company in order to avoid the escalation of force and mitigate the risk of security operations being undertaken without the company's knowledge. The company will need to adhere to the contracting protocols discussed below to ensure that the security provider's personnel are treated appropriately and the company 
has a veto-right in the event it is not satisfied with a service provider's qualifications or performance.

\section{c. Government Security Forces}

Ideally, the host government will also agree that its security forces will adhere to the Voluntary Principles in connection with the provision of security to oilfield operations. A desired approach is that the Department of Energy (or other similar body), the Department of Defense (or other body in charge of providing public security to the oil or gas project), and the oil company will sign a three party memorandum of understanding or agreement governing the security arrangements on site. The practical ability to obtain meaningful commitments and restrictions from the government regarding its use of force will vary and as noted in the IFC Guidebook:

[G]overnment security forces may not be willing to accept restrictions on their powers, including use of force. The Guidance Note suggests that it is nevertheless in companies' best interests to encourage public security forces to act in accordance with the principles of this component ... and with respect for human rights, in order to maintain good relations with the local community. Companies are expected to communicate these expectations to security providers and personnel, including their expectation that security be provided in accordance with these principles by adequately and effectively trained security personnel. ${ }^{191}$

With respect to government militia, the identity, background, and reputation of the military leader in charge of security will be a critical factor and should be carefully investigated. Companies may be required or requested to compensate or equip the security forces for a project. In such cases, companies should "elect where possible to provide in-kind compensation such as food, uniforms or vehicles, rather than cash or weapons,"192 while at the same time ensuring that any such compensation is not offside any anti-corruption legislation, as discussed above. Companies should carefully monitor the conduct of security forces, and any events of misconduct should be promptly reported and addressed.

\section{F. Extraterritorial Litigation And Piercing the Corporate VeIL}

\section{RISK OVERVIEW}

As noted above, the past number of years have seen an increase in efforts by foreign plaintiffs to bring claims in Canadian courts respecting the foreign operations of Canadian resource companies and their subsidiaries. Sean Fairhurst and Zoë Thoms discussed the Hudbay Minerals case and the increased risk of extraterritorial litigation for Canadian parent corporations as Canadian judges are rethinking the legal doctrines that previously stood in the way of granting foreign plaintiffs relief, including the doctrine of piercing the corporate veil."

191 Ibid at 179 [footnotes omitted].

192 Ibid.

Fairhurst \& Thoms, supra note 144 at 392. As noted in this article, former Supreme Court Justice Ian Binnie stated that the doctrine of "piercing the corporate veil" requires rethinking and judicial boldness as it relates to human rights litigation to ensure Canadian companies are held accountable for their activities and that plaintiffs have a meaningful forum in which to bring an action. Justice Binnie does not see adjudication through international tribunals as a realistic option for complaints against extractive industries, due to the sheer quantity of complaints made against them and the inability of the 
Limited liability for shareholders is a fundamental tenet of corporate law which is found in corporate law statutes across Canada. The $A B C A$ states that shareholders are not, as shareholders, liable for any liability, act or default of the corporation, except as otherwise specified under the $A B C A .{ }^{194}$ However, plaintiffs asserting claims against a subsidiary often seek to disregard the corporate form of a subsidiary and try to hold the parent entity directly liable for a subsidiary's obligations. While courts cannot disregard the plain language of limited liability within corporate statutes, courts may provide equitable relief in certain cases by "piercing the corporate veil.",195

Empirical studies conducted in the US have indicated that the piercing the corporate veil doctrine is a frequent action under corporate law. ${ }^{196}$ Piercing cases involving parent-subsidiary relationships are receiving increased attention, and plaintiffs choose to target parent corporations for the actions of their subsidiaries due to the potential for larger financial awards. ${ }^{197}$ However, as stated by Peter Spiro "[g]iven that piercing is a discretionary, equitable remedy, rather than a rule of law, there is less scope for clear rules of precedent to apply to it." 198

There have been a number of high-profile Canadian cases which highlight the application of this doctrine, including:

- Hudbay Minerals ${ }^{199}$ - The plaintiffs argued in a preliminary procedural motion that Hudbay's corporate veil should be pierced to hold it liable for the actions of its subsidiary CGN. ${ }^{200}$ They argued that CGN, the subsidiary which was operating the Fenix Mining Project at the relevant time, was an agent of Hudbay, and "in addition to direct liability, that the corporate veil should be pierced to impose liability on Hudbay for the torts of battery, wrongful imprisonment, and wrongful death committed by CGN's employees or agents." ${ }^{201}$ The Court found that " $[\mathrm{w}]$ hether or not this agency relationship is ultimately found to have existed at the relevant time, the allegation is not patently ridiculous or incapable of proof, and therefore must be taken to be true for the purposes of this motion."202 Justice Brown summarized the generally recognized and accepted grounds for piercing the corporate veil, stating:

Ontario courts have recognized three circumstances in which separate legal [personalities] can be disregarded and the corporate veil can be pierced: (a) where the corporation is

international community to form a consensus to agree on a convention for domestic courts to take jurisdiction.

ABCA, supra note 7, s 15.1. See Peter S Spiro, "Clarifying the Rules for Piercing of the Corporate Veil" (Paper delivered at the University of Toronto - Mowat Centre for Policy Innovation, School of Public Policy and Governance, 4 December 2013) at 7 [unpublished].

Ibid at 6-8.

Robert B Thompson, "Piercing the Corporate Veil: An Empirical Study" (1991) 76:5 Cornell L Rev 1036.

John H Matheson, "The Modern Law of Corporate Groups: An Empirical Study of Piercing the Corporate Veil in the Parent-Subsidiary Context" (2009) 87:4 NCL Rev 1091 at 1095.

Spiro, supra note 195 at 7 . The Supreme Court of Canada has noted that the piercing doctrine "follows no consistent principle" (Kosmopoulos v Constitution Insurance Co, [1987] 1 SCR 2 at 10). Supra note 145.

Compañía Guatemalteca de Níquel (CGN) owned and operated the Fenix mining project and, at relevant times, was wholly controlled and 98.2 percent owned by Hudbay. CGN was subsequently sold, but Hudbay remains responsible for litigation arising from the Hudbay Minerals action.

Hudbay Minerals, supra note 145 at para 43

Ibid at para 49. 
"completely dominated and controlled and being used as a shield for fraudulent or improper conduct"...; (b) where the corporation has acted as the authorized agent of its controllers, corporate or human...; and (c) where a statute or contract requires it. ${ }^{203}$

As a result of the Court's findings, this case is proceeding to be tried on its merits.

- Yaiguaje v. Chevron Corporation ${ }^{204}$ - The Supreme Court of Canada recently heard arguments with respect to an appeal of a motion to stay in this case, pursuant to which plaintiff residents of Ecuador are seeking to enforce an Ecuadorian court judgment made against Chevron Corporation in relation to environmental liabilities of its predecessor Texaco Inc. The defendants to the Canadian action are Chevron Corporation and its Canadian subsidiary Chevron Canada Limited. The Ontario Court of Appeal allowed an appeal of the lower court's decision to stay the action on the basis that the court lacked jurisdiction. ${ }^{205}$ The Court of Appeal stated that the motion judge had made "significant findings about the corporate and legal structures of Chevron and Chevron Canada," and that the viability of the Ecuador plaintiffs' actions regarding piercing the corporate veil deserved to be addressed and determined, if not at a trial, then at least in the context of a record and legal arguments. ${ }^{206}$

\section{Mitigation STRATEgIES}

One of the manners in which entities manage liability risk is by creating corporate subsidiaries with an independent legal identity, distinct from its shareholders or affiliated entities. However, as noted above, even where separate entities are set up to mitigate liability, companies may still be exposed to corporate veil claims especially in cases where the parent corporation contains substantial financial assets as compared to its subsidiaries, or where it could be argued that subsidiaries operate as agents of the parent, as opposed to separate entities.

The cases discussed above illustrate the tension between companies adopting good governance practices and controls on an enterprise-wide basis, and the risk of potential liability exposure through direct liability or piercing the corporate veil claims if too much direct control is exercised by the parent company. Steps that can be taken to minimize the risk of piercing the corporate veil claims to ensure that a separate corporate identity is maintained for the subsidiary include: (1) having the mind and management of the subsidiary properly established to ensure that the subsidiary acts independently and the subsidiary's board conducts its own meetings and engages in appropriate decision-making and board governance; (2) having policies and procedures properly tailored to the relevant jurisdiction

Ibid at para 45. See also Blyschak, supra note 28 at 702; Spiro, supra note 195 at 7-8. See e.g. 642947 Ontario Ltd v Fleischer (2001), 209 DLR (4th) 182 at para 68 (Ont CA); Performance Industries Ltd v Sylvan Lake Golf \& Tennis Club Ltd, 2000 ABCA 116, 185 DLR (4th) 269; Palmolive Manufacturing Co $v$ The King, [1933] SCR 131. It has been noted that "these avenues may be available to "pierce the corporate veil' to attribute foreign corrupt practices committed by a foreign subsidiary to a Canadian parent"(Blyschak, supra note 28 at 702). (4th) 253). The Supreme Court dismissed the appeal. This article reflects the state of the law as of 30 June 2015, and a substantive analysis of this decision is beyond the article's temporal scope. 
and having those policies and procedures properly vetted and approved at the subsidiary board level; (3) properly capitalizing each subsidiary and ensuring arm's length terms for intercompany transactions and maintaining proper documentation of all fund transfers and intercompany and third party contracts and transactions; (4) adequately insuring the subsidiary; and (5) complying with corporate formalities and maintaining separate bank accounts and separate books and financial records. The subsidiary must be established in a way to ensure that the subsidiary is not a mere conduit of the parent "lacking any independent mind, operations, finances, or resources devoted to its international operations." $" 207$

\section{G. Protecting EMployees Abroad}

\section{RISK OVERVIEW}

To the extent a company intends to send Alberta-based employees or contractors abroad, the company may be liable under Alberta law for injuries or death suffered by the Alberta employee in the foreign jurisdiction if the company fails to uphold the required standard of care in the workplace. These losses may potentially include liability for medical bills, lost income, the cost of future care, pain and suffering, the loss of enjoyment of life, dependents' loss of support, and sorrow and grief of survivors. ${ }^{208}$ One high-profile example of the types of risks companies face in sending employees abroad is the al-Qaeda linked terrorist attack that occurred at the Amenas gas plant in Algeria in 2013, in which approximately 130 foreign workers were taken hostage and 39 were killed. ${ }^{209}$ British Petroleum and Statoil, as partial operators of the plant, have been the subject of various inquests and face civil suits from the victims' families. $^{210}$

The following provides a brief overview of liability an employer may face for injuries suffered by an Alberta-based employee who is sent abroad:

- Section 217.1 of the Criminal Code establishes a standard of care for all persons "directing the work of others" to take reasonable steps to ensure the safety of workers and the public. ${ }^{211}$

- If certain criteria are not satisfied, the employer may not be protected from liability under the Alberta Workers' Compensation Act regime. The employee working abroad

Blyschak, supra note 28 at 702-703 (considering this concept in the context of foreign corrupt practices of the subsidiary).

Andrews v Grand \& Toy Alberta Ltd, [1978] 2 SCR 229. The heads of damage that have been enunciated by the Supreme Court of Canada allow recovery for pecuniary loss occurring before trial, non-pecuniary loss, loss of earning capacity, and cost of future care.

See e.g. Anthony DiPaola, "Statoil Returns Expats to Algeria Fields After Attacks," Bloomberg Business (23 January 2014), online: Bloomberg <www.bloomberg.com/news/articles/2014-01-22/statoil-returning -foreigners-to-algeria-gas-fields-after-attacks>; Owen Bowcott, "In Amenas Murders: Coroner Points to Security Flaws at Algerian Gas Plant," The Guardian (26 February 2015), online: <www.theguardian. $\mathrm{com} /$ world/2015/feb/26/in-amenas-murders-coroner-finds-algerian-gas-plant-had-security-flaws $>$. Bowcott, ibid.

Criminal Code, supra note 112, s 217.1 There has not yet been a Canadian case where section 217.1 of the Criminal Code has been considered for workers abroad. See Canadian Centre for Occupational Health and Safety, "Bill C-45 - Overview," online: <www.ccohs.ca/oshanswers/legisl/billc45.html>. As noted in this article, there have been cases where charges and fines were issued using the occupational health and safety legislation of the jurisdiction where the incident took place. 
is entitled to compensation under the Workers' Compensation Act only if certain criteria are satisfied. ${ }^{212}$ If a worker abroad is not eligible for workers compensation for an injury, then the employer may be exposed to a claim in tort.

- Regardless of the standards set forth under local laws in the host country, Alberta's Occupational Health and Safety Act has extra-territorial application to operations abroad, as "Work Site" is defined in the OHSA as: "a location where a worker is, or is likely to be, engaged in any occupation and includes any vehicle or mobile equipment used by a worker," making no reference to the territorial boundaries of Alberta. ${ }^{213}$ The Canadian Industrial Relations Board (CIRB) has found numerous times that the Canadian Labour Code (CLC), which sets out labour, employment, and health and safety laws for federally regulated employers, extends beyond the territorial of limits of Canada. ${ }^{214}$

- The liability at common law depends on some act of negligence, imputable to the employer, which caused the injury and is based on the reasonable foreseeability of the dangerous condition that caused the injury to the employee. ${ }^{215}$ It must be apparent that a lack of care is reasonably likely to endanger the employee's safety. ${ }^{216}$ There have been cases in the UK based on a common law duty of care claim for workers that are employed abroad, and they hinge on whether the situation in the host country was reasonably foreseeable. ${ }^{217}$ The case law in the UK has also established that multinational corporations cannot delegate their duty of care responsibility to their subcontractors or agents. ${ }^{218}$ Further, courts have found that directors can be personally liable for torts when they expressly or impliedly procure the commission of a tortious act, such as where an employee is injured through using defective equipment that the director knew or ought to have known was deficient. ${ }^{219}$

Workers' Compensation Act, RSA 2000, c W-15 [WCA]. Section 28 requires that: (a) the worker is a resident of Alberta or their usual place of employment is in Alberta, and the nature of the employment is such that, in the normal course, the work being performed is required to be performed in and out of Alberta; (b) the employment out of Alberta is a continuation of the employment by the same employer in Alberta; and (c) subject to certain statutory exceptions, the employment out of Alberta has lasted less than 12 continuous months. Occupational Health and Safety Act, RSA 2000, c O-2, s 1(cc) [OHSA].

Examples of this are seen when the CIRB granted a trade union access to employees working on the employer's offshore oilrigs in Seafarers' International Union of Canada v Dome Petroleum Ltd, [1978] 2 Can LRBR 518; Communication Workers of Canada v Bell Canada (1982), 50 di 105 (Can LRB). Grand Trunk Pacific Coast Steamship Co v Victoria-Vancouver Stevedoring Co (1918), 57 SCR 124; Belmont v Smart Manufacturing Co (1905), 6 OWR 942 (Div Ct); Berger v Willowdale AMC (1982), 131 DLR (3d) 585 (Ont HC), aff'd (1983), 41 OR (2d) 89 (CA), leave to appeal to SCC refused, 379320 (17 May 1983) (president of plaintiff's employer owing plaintiff duty of care; foreseeable possibility of injury if dangerous condition not rectified; president personally liable). The question of the common law liability of an employer for injuries suffered by employees during the course of employment has decreased in importance because of the statutory scheme of obligatory compensation for most injured workers (workers' compensation legislation) and the greatly increased amount of legislation setting out compulsory standards of safety in the workplace (occupational health and safety legislation). Wood v Canadian Pacific Railway (1899), 30 SCR 110 (UK plaintiff injured while coupling and uncoupling cars after feet becoming entangled in long grass and weeds; no recovery; railway not negligent in permitting grass and weeds to grow on sidetrack since the risk of injury was too remote). Examples of the duty of care owed by employers in the UK are: Johnson $v$ Coventry Churchill International Ltd, [1992] 3 All ER 14 (QB); Lubbe and others v Cape Plc, [2000] UKHL 41, [2000] 4 All ER 268 (HL (Eng)); Matthews v Kuwait Bechtel Corp, [1959] 2 All ER 345 (CA). Cook v Square D Ltd, [1992] ICR 262 (EWCA). 


\section{Mitigation StRATEgies}

Oil and gas companies will generally have strict policies regarding health, safety, and environment protocols and generally there is a an internal mandate to adhere to international industry standards regardless of where the operations are being conducted. As well, there may be requirements under the host government contract, regulatory approvals, and local laws in the operating jurisdiction that regulate the safety of workers and emergency response requirements. These industry standards and regulations should be carefully evaluated and followed, recognizing the lack of sophistication and enforcement of local rules that may create significant gaps on safety measures in emerging markets.

\section{a. Risk Assessments, Training, and Acknowledgment of Dangers}

Companies must conduct a thorough evaluation of the safety protocols and security of travel to and within the emerging market. The culture of safety and safety practices are often very different in foreign jurisdictions, so thorough training and the creation of safety fundamentals are of critical importance, as well as testing of plans and implementing protocols in locations where communications and transportation may not be reliable. To mitigate the risk of employee claims, some possible actions the company can take include: (1) fully inform its employees of the risks of the operations and ensure that its personnel understand and acknowledge the dangers; (2) make it clear that the position in, and travel to, the location is voluntary; (3) conduct thorough training and, in particular situations, consider whether psychological testing may be appropriate; and (4) adopt measures and take reasonable steps to protect the Alberta employee while he is working abroad. A written acknowledgment of the risks and that travel is voluntary should be obtained from the employee prior to travelling, if possible. This may be a difficult conversation since, on the one hand, the company is asking that the employee undertake travel that may be dangerous, while on the other hand, the company is asking that the employee acknowledge the risks associated with such travel and presumably release the company from any liability arising out of or associated with such risk. Companies may also offer extra compensation as an "area allowance" or "danger pay" to such employees. However, even where extra compensation is paid, employee-signed assumption-of-risk waivers are extremely fragile and may not be enforced, as they are vulnerable on a number of grounds including public policy or undue influence in that the employees are presumptively victims of weaker bargaining power. In addition, it is difficult to address all of the potential risks that should be covered within a release and, without the necessary specificity, the release may not achieve the desired result.

\section{b. Travel, Transportation, and Emergency Response Plans}

Often one of the highest risks for personnel relates to local travel and transportation, including traffic accidents and car jackings. Safety protocols mitigating these risks include: (1) hiring professional drivers and security, and in many places, ensuring that expatriates are not authorized to operate motor vehicles, unless for an emergency; (2) prohibiting the driving of motor vehicles outside city limits at night, unless for emergency or essential operational requirements; (3) pre-arranging transportation to and from local destinations; (4) making certain regions and border areas off-limits and, in high risk regions, requiring bullet proof vests and other protections; (5) setting up and assessing protocols such as a minimum number of vehicles in a convoy and the use of security escorts; (6) tracking travel using journey 
management and protocols to have travelers phone in at specified times and locations, to report their positions and activities; and (7) monitoring government and international warnings and communicating regularly with staff abroad.

The Canadian Trade Commissioner Service suggests that companies should perform a risk assessment of risks such as "crime or civil unrest, terrorism, safety hazards, illnesses and stress." ${ }^{220}$ It also recommends that companies take the following steps to ensure they have met the reasonableness standard of care:

- "plan for an incident by developing a corporate policy for international travel, establishing a response plan for the incident, and creating a family support plan";

- "prepare for an incident by training the traveller, establishing a system to track and support the employee," including identifying contacts within the foreign country (including embassy staff, law firms, and accounting firms) that can be relied upon for quick and appropriate action or advice should circumstances arise while he or she is travelling, and assessing the level of risk and threat based on the location;

- "prevent a potential incident by tracking the traveler and informing him or her about changing events and circumstances"; and

- "respond to an incident by implementing the business continuity plan, supporting family members, and evaluating the incident management system.",221

Other measures which companies should consider implementing within a travel safety program may include:

- obtaining, where appropriate, medical and evacuation coverage to safeguard employees while on assignment;

- $\quad$ ensuring employees become well-acquainted with the Canadian and British Foreign Affairs offices and the US State Department's websites, which have country-specific information concerning threats to safety and security, areas of political and social instability, recommended health immunizations, and restricted areas within the country; and

- providing the employees with emergency contact information for local law enforcement, health care providers, and other emergency service providers.

Evacuation protocols and emergency response plans must be carefully prepared and tested on a location-by-location basis. Companies will need to conduct site visits to evaluate the execution of plans, including accessibility, location of landing strips, types of vehicles to be utilized, and whether cash funds will be available and can be safely stored to facilitate the safe treatment and evacuation of the company's staff. Channels of communication must be 
developed and tested and back-up solutions must be secured for civil unrest situations. Companies need to be mindful to be able to respond to protect their own people and contractors, and possibly may need to protect communities that may be affected by an incident. "Local infrastructure and resources should be front of mind for companies planning for emergencies.... [C]ompanies may need to supplement local resources or appropriately equip projects themselves to be able to effectively respond to emergencies that endanger lives or property of Affected Communities." 222 This will be particularly important in remote regions with limited infrastructure.

\section{H. Contracting ANd Insurance Protocols}

\section{RISK OVERVIEW}

Oil and gas projects will involve a significant number of agreements with various counterparties, and the level of sophistication of those parties, operating standards and insurance protocols will vary widely. Companies will be at risk of unallocated risks and losses if they do not carefully identify the key risk areas for the project, how those risks are allocated under various contracts, whether those risks are insurable, and the interplay among the various insurance policies that may apply. As well, emerging markets present heightened risks of fraud, bribery, or kickbacks in the procurement area that must be properly investigated and controlled.

\section{Mitigation STRATEGIES}

\section{a. Contracting and Procurement Protocols}

Companies, depending on their size, will have various levels of sophistication and standardization regarding their contracting and procurement protocols. There should be a thorough understanding of the allocation of responsibility and risk under third party contracts. In some situations, the contractor may be in the best position to manage various risk areas in emerging markets. For example, they may be in the best position to hire security and may have developed relationships in a region where a new entrant is not familiar. Risk sharing and risk allocation will be important considerations for legal and procurement groups, and they will impact the costs of services, insurance placement and other considerations.

In terms of contract allocation of responsibility, as compared to most North American risk allocation regimes that allocate liability based on fault (with certain negotiated carve-outs or monetary caps), it is common that, for international projects: (1) there will be a "knockfor-knock" indemnification structure whereby each party is responsible for and indemnifies the other party against injury, death, or property damage for its own personnel; (2) liability for injury/damage to third parties is allocated based on which party caused the damage; (3) each party is liable for its failure to comply with applicable law or breach of contract; and

(4) parties agree that there will be no awards of consequential, indirect or punitive damages. Notwithstanding which risk allocation regime is adopted, it is critical that only one consistent 
regime is adopted and applies to a worksite or operation. Failure to do so can result in inconsistencies, unexpected consequences, and unallocated losses.

In addition, where a contractor contemplates hiring local labour as part of its personnel, it may be necessary for the company to specify the type of food and accommodation that is to be supplied to such personnel in order to mitigate against the risk of labour unrest that could both negatively affect a company's operations and increase the risk of disturbances. The company should also ensure that any contract it enters into grants the company a veto right with respect to the qualifications and performance of the personnel being utilized by the contractor. The company should take into account cultural considerations on hiring practices for itself and its contractors when local personnel are being utilized, especially in regions where there may be tensions between various cultural, religious, and ethnic minority and majority populations.

Companies should also ensure that appropriate protections and due diligence are adopted to reduce the risk of fraud and corruption. The procurement group should adhere to bidding requirements and have protocols to vet and authorize third-party suppliers and vendors to ensure they have the appropriate skills, qualifications, resources, insurance, and equipment to provide the required services and functions, as well as that the costs for services and goods are appropriate and competitive. In addition to operational risks and delays that may occur if the company does not engage properly qualified service providers, efforts must also be made to prevent private fraud, bribery, and kickbacks, as well as corruption of public officials that may be masked through third party contractors. Companies should implement strict internal controls and authority guidelines to ensure that contracts and expenditures are legitimate and properly authorized.

\section{b. Insurance}

Insurance is a key element of risk management. The scope and limitations on coverage must be carefully reviewed by internal or external insurance experts. In addition to general corporate insurance policies, specific insurance requirements may be included in the host government contract, under local laws, in joint venture agreements, in service contracts, or other third party agreements. There may be special insurance requirements desired for war risk, political risk, terrorism risk, and kidnapping/ransom risk, however the coverage may at times, be cost-prohibitive. A number of these types of policies are entered into because of associated benefits in addition to the financial coverage. For example, kidnapping/ransom insurance usually includes the provision of expert negotiators. Again, the company's insurance program applicable to a particular project and its interplay with the insurance of other third parties must be carefully vetted to ensure consistency, and that the company knows which losses are covered and which are self-insured. 


\section{Conclusion}

Oil and gas companies are constantly in search of accretive opportunities to expand their resource base and create value. Emerging markets can provide companies with opportunities for significant rewards, especially in regions where oil and gas resources may be underdeveloped and where new technologies have not yet been exploited. However, emerging markets also pose numerous challenges and risks, which can potentially lead to significant legal and reputational damage, and companies may be targeted by enforcement authorities, securities commissions, indigenous groups, class action litigants, and other claimants should an incident occur. Directors and officers need to ensure that, when overseeing a company's operations in emerging markets, they are meeting their requisite corporate law duties by staying properly informed about key risks (which will differ significantly from domestic operations) and implementing an effective risk management system to identify and manage risks appropriately. The risk management system should be developed to operate both at the time of the original investment decision and on a continuous basis throughout the life of the project to identify and reassess risks in an ever-changing political, legal, cultural, and operational landscape. Ideally, the risk management system will effectively identify and prioritize the key risks applicable to a particular project in a particular location, considering risks highlighted in this paper related to the nature of the investment, political risk, corruption risk, human rights and community relations risks, security risk, extraterritorial litigation and piercing the corporate veil, labour risk, and contracting and insurance risks. In conjunction with identifying and prioritizing these risks (which must be done on a continual basis), directors and management must ensure that the appropriate mitigation measures are implemented, consisting of both proactive measures to prevent or mitigate against anticipated or known risks, as well as reactive measures which can be relied on should an incident arise. Companies often find themselves in challenging situations and missteps are common in these ever-changing regions of the world. However, through proper due diligence and planning, companies can better understand and manage the risks and better position themselves to capture the rewards in emerging markets. 


\section{APPENDiX A: \\ CANADA's CORPORATE SOCIAL RESPONSIBILITY STRATEGY}

Following a series of CSR strategy consultations with industry, the Enhanced CSR Strategy was announced by the Canadian government in November 2014 entitled Doing Business the Canadian Way: A Strategy to Advance Corporate Social Responsibility in Canada's Extractive Sector Abroad. ${ }^{223}$ The original CSR strategy, ${ }^{224}$ which was announced in 2009, was developed to provide CSR guidance and support to Canadian extractive sector companies working in developing countries, recognizing that such companies were investing substantial amounts of money to develop resources in host countries that have complex and challenging social and environmental risks. ${ }^{225}$ The Canadian government identified four key initiatives it would undertake as part of the original CSR strategy: (1) supporting initiatives to enhance the capacities of developing countries to manage the development of minerals and oil and gas, and to benefit from those resources to reduce poverty; (2) promoting certain international CSR performance guidelines with Canadian extractive companies operating abroad; (3) establishing an Office of the Extractive Sector CSR Counsellor (CSR Counsellor) to assist stakeholders in the resolution of CSR issues pertaining to the activities of Canadian extractive sector companies abroad; and (4) supporting the development of a CSR Centre of Excellence within an existing institution outside of government to encourage the Canadian international extractive sector to implement the Endorsed Principles by developing and disseminating high-quality CSR information, training, and tools. ${ }^{226}$

The Office of the CSR Counsellor was established in 2009 to act both as an advisory office to promote the implementation of the Endorsed Principles (the Advisory Mandate), as well as to establish and oversee a dispute resolution process to resolve conflicts arising between Canadian extractive sector companies operating abroad and the project-affected stakeholders (the Review Process). ${ }^{227}$

\section{ADVISORY MANDATE AND ENDORSED PRINCIPLES}

The purpose of the CSR Counselor's Advisory Mandate is to encourage stakeholders to implement the Endorsed Principles in order to prevent and reduce conflict between Canadian extractive corporations operating abroad and their applicable project-affected stakeholders. ${ }^{228}$ The Endorsed Principles advocate CSR principles and reporting standards which assist corporations in managing and mitigating their operations risk through assessing the impact of projects on multiple stakeholders and fostering stakeholder engagement. The Endorsed

\footnotetext{
223 Supra note 4.

224 Foreign Affairs, Trade and Development Canada, "Corporate Social Responsibility: Building the Canadian Advantage: A Corporate Social Responsibility (CSR) Strategy for the Canadian International Extractive Sector," online: <www.international.gc.ca/trade-agreements-accords-commerciaux/topicsdomaines/other-autre/csr-strat-rse-2009.aspx?lang=eng $>$.

225 Ibid.

226 Ibid.

227 Foreign Affairs, Trade and Development Canada, "Office of the Extractive Sector Corporate Social Responsibility (CSR) Counsellor - About Us," online: <www.international.gc.ca/csr_counsellorconseiller_rse/about-us-a-propos-du-bureau.aspx?lang=eng > [“CSR Counsellor About Us"].

228 Foreign Affairs, Trade and Development Canada, "Office of the Extractive Sector Corporate Social Responsibility (CSR) Counsellor — Our Advisory Role,” online: <www.international.gc.ca/csr counsellor-conseiller_rse/advisory-role-role-consultatif.aspx?lang=eng $>$.
} 


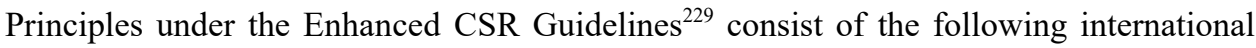
standards:

\begin{tabular}{|c|c|}
\hline Endorsed Principle & Description \\
\hline $\begin{array}{l}\text { International Finance Corporation (IFC) } \\
\text { Performance Standards on Social \& } \\
\text { Environmental Sustainability for Extractive } \\
\text { Projects with Potential Adverse Social or } \\
\text { Environmental Impacts (IFC Standards) }\end{array}$ & $\begin{array}{l}\text { The IFC Standards are standards developed by the IFC for the purposes } \\
\text { of identifying and managing environmental and social risk associated } \\
\text { with project investments in developing countries. The IFC Standards } \\
\text { apply to all investment and advisory clients of the IFC whose projects go } \\
\text { through the IFC's initial credit review process. However, the IFC } \\
\text { standards have become an internationally recognized set of standards for } \\
\text { assisting corporations in identifying and managing environmental and } \\
\text { social risk in developing countries where their operations are located. } \\
\text { The IFC Standards consist of standards relating to a variety of } \\
\text { environmental and social issues including: (1) land acquisition and } \\
\text { involuntary resettlement; (2) indigenous peoples; and (3) resource } \\
\text { efficiency and pollution prevention. }\end{array}$ \\
\hline $\begin{array}{l}\text { Voluntary Principles on Security and } \\
\text { Human Rights for Projects Involving } \\
\text { Private or Public Security Forces (the } \\
\text { Voluntary Principles) } \text { ) }^{231}\end{array}$ & $\begin{array}{l}\text { The Voluntary Principles were developed by various participants, } \\
\text { including government representatives from the US and UK, companies } \\
\text { involved in the extractive and energy sectors, and non-governmental } \\
\text { organizations, to guide companies in maintaining the safety and security } \\
\text { of their operations within an operating framework that encourages } \\
\text { respect of human rights. The Voluntary Principles set out principles } \\
\text { dealing with assessing security risks, managing interactions with public } \\
\text { security forces, and managing interactions with private security } \\
\text { providers. }\end{array}$ \\
\hline
\end{tabular}

Supra note 4 at $6-7$

International Finance Corporation, Performance Standards on Environmental and Social Responsibility (1 January 2012), online: <www.ifc.org/wps/wcm/connect/115482804a0255db96Fbffd1a5d13d27/PS
English_2012_Full-Document.pdf?MOD=AJPERES>.

Supra note $18 \overline{7}$. 


\begin{tabular}{|c|c|}
\hline Endorsed Principle & Description \\
\hline $\begin{array}{l}\text { Global Reporting Initiative for CSR } \\
\text { Reporting by the Extractive Sector to } \\
\text { Enhance Transparency and Encourage } \\
\text { Market-based Rewards for Good CSR } \\
\text { Performance (GR Initiative Standards) }\end{array}$ & $\begin{array}{l}\text { The GR Initiative Standards set out reporting guidelines to enable } \\
\text { corporations to measure, understand, and communicate information with } \\
\text { respect to the economic, environmental, and social impacts caused by a } \\
\text { corporation's activities. Corporations can use the GR Initiative Standards } \\
\text { to produce sustainability reports which assist corporations in identifying } \\
\text { the tangible effects of their CSR policies on their operations. Reporting } \\
\text { categories and sub-categories cover a wide range of topics including: } \\
\text { economic performance, environmental compliance, labour practices, } \\
\text { human rights compliance, anti-corruption measures, and product } \\
\text { responsibility. }{ }^{232} \text { In addition, report content is guided by certain } \\
\text { principles including: (1) requiring the corporation to identify corporate } \\
\text { stakeholders and how the corporation has responded to their reasonable } \\
\text { expectations and interests; ( } 2 \text { ) ensuring the corporation's performance is } \\
\text { presented within the wider context of sustainability, and (3) ensuring } \\
\text { information is presented in a manner that enables stakeholders to analyze } \\
\text { changes in the organization's performance over time. }{ }^{233}\end{array}$ \\
\hline $\begin{array}{l}\text { The OECD Guidelines for Multinational } \\
\text { Enterprises (MNE Guidelines) }{ }^{234}\end{array}$ & $\begin{array}{l}\text { The MNE Guidelines are guidelines developed by the OECD which set } \\
\text { out voluntary principles and standards for responsible social, economic, } \\
\text { and environmental conduct by multinational enterprises, consistent with } \\
\text { domestic and international laws. The MNE Guidelines contain } \\
\text { recommended performance standards for multinational enterprises which } \\
\text { cover a variety of topics including human rights, employment and } \\
\text { industrial relations, environmental laws, and bribery and extortion. The } \\
\text { MNE Guidelines are recognized as an endorsed performance standard by } \\
\text { the CSR Counsellor, although Canada's National Contact Point office } \\
\text { chaired by the Department of Foreign Affairs } \\
\text { and International Trade, remains the primary authority with respect to the } \\
\text { implementation of the MNE Guidelines. }\end{array}$ \\
\hline
\end{tabular}
Initiative, 2013) at 9, online: <www.globalreporting.org/resourcelibrary/GRIG4-Part1-ReportingPrinciples-and-Standard-Disclosures.pdf $\$$. Ibid at $16-18$.

The Organisation for Economic Co-operation and Development, OECD Guidelines for Multinational Enterprises (OECD Publishing, 2011), online: <www.oecd-ilibrary.org/oecd-guidelines-for-multi national-enterprises $5 \mathrm{kgdp} 616 \mathrm{ch} 8 \mathrm{w} . \mathrm{pdf} ?$ content Type $=\% 2 \mathrm{fns} \% 2 \mathrm{fBook} \% 2 \mathrm{c} \% 2 \mathrm{fns} \% 2 \mathrm{fOECDBook} \&$ itemId $=\% 2$ fcontent $\% 2$ fbook $\% 2$ f9789264115415-en\&mimeType $=$ application $\% 2$ fpdf\&containerItemId $=\% 2$ fcontent $\% 2$ fbook $\% 2$ f $9789264115415>$. 


\begin{tabular}{|c|c|}
\hline Endorsed Principle & Description \\
\hline $\begin{array}{l}\text { United Nations Guiding Principles on } \\
\text { Business and Human Rights (UN } \\
\text { Principles) }{ }^{235} \\
\text { *added in } 2014\end{array}$ & $\begin{array}{l}\text { The UN Principles were endorsed by the UN Human Rights Council in } \\
\text { June } 2011 \text { and identify the complementary responsibilities of companies } \\
\text { and government with respect to human rights, including the corporate } \\
\text { responsibility to respect human rights through due diligence. The UN } \\
\text { Principles set out a "Protect, Respect and Remedy" framework for } \\
\text { corporations to meet their respective human rights responsibilities, which } \\
\text { corporate actions include at a minimum: (1) a policy commitment to meet } \\
\text { its responsibility to respect human rights; (2) a human rights due } \\
\text { diligence process to identify, prevent, mitigate, and account for how it } \\
\text { addresses its impact on human rights; and (3) processes to enable the } \\
\text { remediation of any adverse human rights impacts it causes or to which it } \\
\text { contributes. }\end{array}$ \\
\hline $\begin{array}{l}\text { The OECD Due Diligence Guidance for } \\
\text { Responsible Supply Chains of Minerals } \\
\text { from Conflict-Affected and High-Risk } \\
\text { Areas (OECD Diligence Guidance) }\end{array}$ & $\begin{array}{l}\text { The purpose of the OECD Diligence Guidance is to mitigate } \\
\text { multinational corporations fuelling conflict through sourcing minerals by } \\
\text { encouraging responsibly sourced and traded minerals through } \\
\text { implementing proper due diligence processes. The OECD Diligence } \\
\text { Guidance sets out a five-step framework for risk-based due diligence, } \\
\text { which includes: (1) establishing strong company management systems, } \\
\text { (2) identifying and assessing risk within the supply chain, (3) designing } \\
\text { and implementing strategies to respond to identified risks, (4) carrying } \\
\text { out independent third-party audits of supply chain due diligence at } \\
\text { identified points in the supply chain, and (5) reporting on supply chain } \\
\text { due diligence. }\end{array}$ \\
\hline
\end{tabular}

\section{REVIEW PROCESS}

The Review Process is the voluntary dispute resolution process provided by the CSR Counsellor for the purposes of resolving conflicts arising between Canadian extractive sector companies operating abroad and the project-affected stakeholders. ${ }^{237}$ Provided the requester has already attempted to engage with the other side to resolve the dispute, the CSR Counsellor will screen the request to determine whether it is an issue connected to the Endorsed Principles. ${ }^{238}$ If so, the CSR Counsellor will work with the participants to facilitate communications and engage in a facilitated mediation process to resolve the dispute. ${ }^{239}$

Supra note 153.

Organisation for Economic Co-operation and Development, OECD Due Diligence Guidance for Responsible Supply Chains of Minerals from Conflict-Affected and High-Risk Areas, 2nd ed (Paris: OECD, 2012) Annex I, online: <www.oecd.org/daf/inv/mne/GuidanceEdition2.pdf>.

"CSR Counsellor About Us," supra note 227. In order to initiate the Review Process, a request for review is submitted to the CSR Counsellor by either the Canadian corporation or the project-affected stakeholder: see Foreign Affairs, Trade and Development Canada, "Office of the Extractive Sector Corporate Social Responsibility (CSR) Counsellor - The Review Process," online: <www. international.gc.ca/csr_counsellor-conseiller_rse/review_process-processus_examen.aspx?lang=eng $>$ [Office of CSR - Review Process]).

Ibid.

Ibid. 
Although six complaints were made to the prior CSR Counsellor before she left the office in 2013, she had little success in mediating them. ${ }^{240}$ The Office of the CSR Counsellor has been heavily criticized since the enactment of the CSR strategy in 2009 for providing little incentive for companies to participate in the process, as the CSR Counsellor's role was limited to facilitating dialogue and the CSR Counsellor did not have the power to investigate any of the complaints received or to report whether a corporation was acting in breach of any of the Endorsed Principles.

The 2014 Enhanced CSR Strategy includes the following two new measures designed to strengthen the Review Process. First, the Enhanced CSR Strategy is designed to strengthen the CSR Counsellor's Review Process by expressly linking it with the Government's OECD National Contact Point (NCP) dispute resolution process with respect to the MNE Guidelines. According to the Enhanced CSR Strategy, when the CSR Counsellor's mediation efforts have not been successful, the Counsellor "will encourage and help parties" to refer their issues to the NCP. ${ }^{241}$ The NCP process, which has been in effect since 2000 and is managed by DFATD, is generally regarded as more effective than the process established to date by the CSR Counsellor. Second, while the Enhanced CSR Strategy still describes the Review Process as voluntary, it makes for the first time, the Government's "economic diplomacy" conditional on a Canadian company's alignment with the Enhanced CSR Strategy. ${ }^{242}$ The Government will withdraw trade commissioner and other support from companies that refuse to participate in the Review Process or that are "found not to be embodying CSR best practices." "243 In addition, it states that this "designation" will be taken into account in the CSR-related evaluation and due diligence conducted by Export

Out of the six complaints, three complaints were closed as the companies declined to participate in the Review Process, and one complaint was closed because of an inability of the CSR Counsellor to establish communications with the Indigenous complainants: see MiningWatch Canada, "The Federal CSR Counsellor Has Left the Building - Can We Now Have An Effective Ombudsman Mechanism for the Extractive Sector?" (1 November 2013)" MiningWatch Canada (blog), online: <www.miningwatch. ca/blog/federal-csr-counsellor-has-left-building-can-we-now-have-effective-ombudsman-mechanismextracti>). The six requests for review related to the following: (i) Golden Arrow Resources Corporation, Argentina, the request for review related to the adequacy of consultation by Golden Arrow with affected indigenous communities with respect to its mining project. The Office of the CSR Counsellor was unable to establish effective communication with the requesters and the file was closed; (ii) Silver Standard Resources Inc, Argentina, the request for review related to concerns of the indigenous population about the environmental impact of Silver Standard's mining project. Silver Standard declined to participate in the dispute resolution process and the file was closed; (iii) New Gold Inc, Mexico, the request for review related to concerns by the local inhabitants regarding New Gold's community engagement with respect to its mining project. The CSR Counsellor conducted dispute analysis, in which New Gold actively participated. This file is now closed. However, the final closing report was not yet available at the time of writing this paper; (iv) McEwen Mining Inc, Argentina, the request for review related to concerns from The Centre for Human Rights and Environment and Ciudadanos Independientes, which were concerned about the impact of McEwen's mining project on the glacial environment. McEwen declined to participate in the dispute resolution process and the file was closed; (v) First Quantum Minerals Limited, Mauritania, the request for review related to concerns by community stakeholders about stakeholder engagement, environmental, and labour issues relating to First Quantum's mining project. First Quantum participated in the dispute resolution process; and (vi) Excellon Resources Inc, Mexico, the request for review related to concerns by Excellon's workers, the National Mining Union of the Mexican Republic and Proyecto de Derechos Economicos, Sociales y Culturales A.C. regarding violations of the Voluntary Principles on Security and Human Rights and violations of the OECD Guidelines for Multinational Enterprises. Excellon declined to participate in the dispute resolution process and the file was closed. No new requests for review have yet been received by the CSR Counsellor at the time of writing this article. Supra note 4 at 12 .

Ibid. At the same time, the Government will increase support for CSR initiatives in Canada's diplomatic network and missions abroad to assist Canadian businesses and local communities. Ibid. 
Development Canada in considering the availability of financing or other support for companies. $^{244}$

\section{APPENDIX B:}

\section{SUMMARY OF THE EXTRACTIVE SECTOR TRANSPARENCY MEASURES ACT}

1. Applicability - Who Must Report - The Act is broad in scope, requiring reporting from: "(a) an entity that is listed on a stock exchange in Canada; (b) an entity that has a place of business in Canada, does business in Canada or has assets in Canada and that, based on its consolidated financial statements, meets at least two of the following conditions for at least one of its two most recent financial years: (i) it has at least $\$ 20$ million in assets, (ii) it has generated at least $\$ 40$ million in revenue, (iii) it employs an average of at least 250 employees; and (c) any other prescribed entity." ${ }^{245}$ It defines "Entity" as "a corporation or a trust, partnership or other unincorporated organization $^{246}$ (a) that is engaged in the commercial development of oil, gas or minerals in Canada or elsewhere; or (b) that controls a corporation or a trust, partnership or other unincorporated organization that is engaged in the commercial development of oil, gas or minerals in Canada or elsewhere."247

2. Obligations - What Must be Reported - The Act requires reporting for any "Payment" given to a "Payee." The definition of Payment includes: "a payment — whether monetary or in kind — that is made to a payee in relation to the commercial development of oil, gas or minerals and that falls within any of the following categories of payment: (a) taxes, other than consumption taxes and personal income taxes; (b) royalties; (c) fees, including rental fees, entry fees and regulatory charges as well as fees or other consideration for licences, permits or concessions; (d) production entitlements; (e) bonuses, including signature, discovery and production bonuses; (f) dividends other than dividends paid as ordinary shareholders; (g) infrastructure improvement payments; or (h) any other prescribed category of payment." ${ }^{248}$ A "Payee" is any government in Canada or in a foreign state, a joint government body, any board, commission, or authority that is established to perform a duty or function of government and any other prescribed payee. ${ }^{249}$ The reporting obligation applies to payments to a government in Canada as well as foreign governments, and is broadly worded such that it will also capture any payments made to Aboriginal governments in Canada, although the reporting requirements for payments made to Aboriginal governments will be delayed for two years following the ESTMA coming into force. ${ }^{250}$ Disclosure is compulsory for any payments in a category of payment (as listed above) made to the same payee if the total of those

Ibid at 12-13.

ESTMA, supra note 5, s 8 .

Wholly owned subsidiaries are deemed to have filed and met the ESTMA's requirements where their parent's reporting includes their payments and they inform the Minister in writing that the parent company is filing for them: ibid, $\mathrm{s} 11$.

Ibid, s 2 .

Ibid.

Ibid.

Ibid, s 29. 
payments in the financial year is at least the amount that will be prescribed in the regulation for that category of payment, or where there is no amount prescribed, $\$ 100,000 .^{251}$ In addition, the Minister may specify how payments are to be broken down and may require reporting at the project level, meaning that the Minister has the authority to require reporting by companies including what payments were made to a government with respect to a specific project as opposed to simply the total amount of annual payments that may have been made to such government.

3. Timing-Reports must be submitted no later than 150 days after the end of a financial year. ${ }^{252}$ Reporting will not be required in respect of the year when the reporting requirements come into force or for any prior year. ${ }^{253}$ Accordingly, the first reporting obligations will be in 2017 in respect of payments made in 2016. The reporting requirements under the ESTMA will apply to payments made to Aboriginal governments in Canada starting two years after the ESTMA comes into force (which means reporting would be required for Aboriginal government payments made after 1 June 2017). ${ }^{254}$

4. Substitution - Importantly section 10(1) of the ESTMA explains that the Minister may allow for substitution of these requirements for another jurisdiction's reporting requirements. Where a foreign jurisdiction's requirements are deemed to be sufficient as a substitute, adherence to the foreign jurisdiction's requirements and submission of the foreign jurisdiction report to the Canadian authority will be sufficient. ${ }^{255}$

5. Offences - Consequences for Non-Reporting - Offences under the ESTMA include: failure to report, failure to make reporting public, failure to keep records with regard to payments, knowingly making a false or misleading statement or knowingly providing false or misleading information (including with regard to which category a payment is made under), and structuring payments in such a way so as to avoid reporting under the ESTMA. Each offence is punishable by a fine of not more than $\$ 250,000 .^{256}$ The Act specifies that if an offence is committed or continued on more than one day, each day is counted as a separate offence, ${ }^{257}$ so the $\$ 250,000$ maximum is only a per day maximum. Section 25 deals directly with liability of officers and directors and reads: "If a person or an entity commits an offence under this Act, any officer, director or agent or mandatary of the person or entity who directed, authorized, assented to, acquiesced in or participated in its commission is a party to and guilty of the offence and liable on conviction to the punishment provided for the offence, whether or not the person or entity has been prosecuted or convicted." ${ }^{258}$ In a prosecution for an offence under the ESTMA "it is sufficient proof of the offence to establish that it was committed by an employee or agent or mandatary of the accused, whether or not the employee or agent or mandatary is identified or has been 
prosecuted for the offence" ${ }^{259}$ There is a five year limitation period starting at the time when the subject matter of the proceedings arose. Section 26(b) provides a due diligence defense stating that no person or entity is to be found guilty of the offence if they establish that they exercised due diligence to prevent its commission. ${ }^{260}$ 